\title{
MANAJEMEN SUMBER DAYA MANUSIA PENDIDIKAN ISLAM (UPAYA MENUNU MASYARAKAT EKONOMI ASEAN (MEA))
}

\author{
Suhada \\ Sekolah Tinggi Agama Islam Alhikmah (STAI) Alhikmah Jakarta \\ *suhada73@yahoo.com
}

\begin{abstract}
ABSTRAK
Tulisan ini bertujuan untuk menjawab pertanyaan bagaimana upaya pengembangan manajemen SDM di MI ICP Nurul Ulum LP Ma'arif NU Bojonegoro dan MI Muhammadiyah 10 Bojonegoro dalam menghadapi Masyarakat Ekonomi Asean? Jenis penelitian ini adalah penelitian kualitatatif. Sumber data dalam penelitian dibedakan menjadi dua macam, yaitu: primer berupa wawancara langsung dengan Kepala Sekolah MINU ICP Bojonegoro dan Kepala Sekolah MIM 10 Bojonegoro dan stafstafnya yang menjalankan dalam pengembangan SDM pendidik, dengan tujuan untuk menggali lebih dalam dan mendapatkan informasi yang dibutuhkan secara detail dan menyeluruh. Sedangkan sumber sekunder merupakan sumber data yang tidak langsung memberikan data kepada pengumpul data, misalnya lewat dokumen, foto dan lain-lain yang berkaitan dengan data yang dibutuhkan peneliti di MINU ICP Bojonegoro dan MIM 10 Bojonegoro. Penelitian ini menghasilkan kesimpulan bahwa upaya-upaya pengembangan sumber daya manusia pendidikaan di MINU ICP Bojonegoro dan MIM 10 Bojonegoro dalam menghadapi era MEA, di antaranya: mengikuti perkembangan jaman, giat dalam palatihan dan wordshop, berkomitmen untuk mencerdaskan anak bangsa, dan berfikir untuk maju di masa yang akan datang.
\end{abstract}

Keyword: Sumberdaya manusia, sumber daya pendidikan, Masyarkat Ekonomi Asean.

\begin{abstract}
ABSTRACK
his paper aims to answer the question of how to develop human resource management in MI ICP Nurul Ulum LP Ma'arif NU Bojonegoro and MI Muhammadiyah 10 Bojonegoro in dealing with the Asean Economic Community? This type of research is a qualitative research. Data sources in the study were divided into two types, namely: primary in the form of direct interviews with the Head of MINU ICP Bojonegoro and the Principal of MIM 10 Bojonegoro and his staff who carried out the development of educator human resources, with the aim of digging deeper and getting the information needed in a detailed and thorough. While secondary sources are data sources that do not directly provide data to data collectors, for example through documents, photos and other matters relating to data needed by researchers at MINP ICP Bojonegoro and MIM 10 Bojonegoro. This research concludes that efforts to develop education human resources at MINP ICP Bojonegoro and MIM 10 Bojonegoro in facing the MEA era include: following the changing times, being active in training and wordshop, committed to educating the children of the nation, and thinking to advance in the future future.
\end{abstract}

Keyword: Human resources, educational resources, ASEAN Economic Community. 


\section{PENDAHULUAN}

Kajian penelitian ini difokuskan pada aspek manajemen pendidikan Islam dan pengembangan sumber daya manusia (SDM) dalam merespon Masyarakat Ekonomi Asean.

Globalisasi merupakan keniscayaan bagi semua bangsa, termasuk Indonesia. Bangsa Indonesia juga sudah merasakan bagaimana manis dan pahitnya terbawa arus globalisasi. Globalisasi akan membawa perubahan yang mencakup semua aspek kehidupan termasuk bidang teknologi, bidang sosial dan bidang pendidikan. Kemajuan di bidang teknologi informasi dan komunikasi itu sudah terealisasi adanya transaksi bisnis cukup dengan komputer dan Hand Phone seperti belanja, jasa bahkan belajar atau kuliahpun dengan cara online. Jasa perbankan sekarang sudah di saku dan genggaman tangan. Rentang jarak antar benua sudah bukan lagi hambatan bagi manusia untuk komunikasi melalui berbagai sosial media. Perkembangan teknologi dijadikan sebuah media pendidikan yang menghibur dan hiburan menjadi pendidikan. Dengan adanya hiburan menjadi pendidikan, proses pendidikan akan semakin menarik dan menghasilkan lulusan yang semakin berkualitas dalam menghadapi era globalisasi. ${ }^{1}$

Pengaruh globalisasi ini dapat mendidik masyarakat untuk memiliki pola pikir responsif dan pola pikir daya saing, suka kerja keras, mau belajar untuk meningkatkan ketrampilan dan prestasi kerja. Dari jaman global ini, kita hidup di dalam dunia yang terbuka, dunia yang tanpa batas. Perdagangan bebas serta semakin meningkatnya kerja sama antar negara memerlukan manusia-manusia yang berkualitas tinggi. Kehidupan global merupakan tantangan sekaligus membuka peluang-peluang baru bagi pembangunan ekonomi dan bagi SDM Indonesia yang berkualitas tinggi untuk memperoleh kesempatan kerja di luar negeri. Disinilah tantangan sekaligus peluang bagi peningkatan mutu pendidikan Indonesia baik untuk memenuhi SDM yang berkualitas bagi kebutuhan di negeri sendiri maupun manca negara. $^{2}$

Salah satu ciri penting era globalisasi adalah tingginya tingkat persaingan yang meliputi hampir di semua lini kehidupan, tidak terkecuali dalam dunia ilmu pengetahuan dan teknologi. Kemajuan ilmu pengetahuan dan teknologi menjadi dasar sekaligus ujung tombak berkembangnya informasi global yang menjadi sebab lahirnya budaya global yang berdampak pada berubahnya pola perilaku manusia. Idealnya perubahan besar tersebut mampu meningkatkan mutu sumber daya manusia disegala bidang. Pada akhir bulan September yang lalu, World Economic Forum (WEF) melansir sebuah laporan tentang tingkat daya saing negara-negara di dunia Global Competitiveness Index (GCI) untuk tahun 2017-2018. Ratusan negara di dunia dinilai dan teliti, seberapa berkualitas dan mampu bersaing setiap negara. Indonesia termasuk dalam daftar kajian tersebut dan kabar baiknya di tahun ini, Merah Putih mengalami peningkatan peringkat. ${ }^{3}$

\footnotetext{
${ }^{1}$ Era Glogal abad 21 ini sungguh memiliki banyak tantangan yang harus siap dan sigap dilakukan oleh segenap umat manusia untuk bisa berbenah diri dalam peningkatan SDM (Sumber Daya Manusia) didalamnya, termasuk pula ada upaya meningkatan kualitas dan kuantitas ekonomi. Perkembangan yang cepat di bidang tekhnologi, diikuti dengan pertumbuhan ekonomi yang tidak kalah cepatnya akan berdampak pada aspek kultural dan nilai-nilai suatu bangsa. M. Hidayat Ginanjar, "Tantangan dan Peluang Lembaga Pendidikan Islam di Era Masyarakat Ekonomi Asean (MEA)”, Edukasi Islami Jurnal Pendidikan Islam, jilid IV (Juli 2015), h. 1012

${ }^{2}$ M. Hidayat Ginanjar, "Tantangan dan Peluang Lembaga Pendidikan Islam di Era Masyarakat Ekonomi Asean (MEA)", h. 74

${ }^{3}$ WEF mengungkapkan bahwa pihaknya menggunakan 12 pilar untuk mengukur daya saing yang menjadi penentu dari pertumbuhan jangka panjang dan faktor esensial dalam pertumbuhan ekonomi dan kesejahteraan. 12 pilar tersebut diantaranya adalah Insitusi (Insitutions), Infrastruktur (Infrastructure), Lingkungan Makro ekonomi (Macroeconomic Environment), Kesehatan dan Pendidikan Primer (Health and Primary Education), Pendidikan Tinggi dan Pelatihan Peterampilan (Higher Education and training), Efisiensi pasar barang (Goods Market Efficiency), Efisiensi pasar tenaga kerja (Labour Market Effiency), Pengembangan pasar Finansial (Financial market development), Kesiapan Teknologi (Techological readiness), Besaran pasar (Market Size),
} 
Sejarah MEA diawali dari perjanjian bersama pada Konferensi Tingkat Tinggi (KTT) yang digelar di Kuala Lumpur, Malaysia yang menghasilkan satu visi bersama negara-negara Asia Tenggara (ASEAN Vision 2020). Tujuannya menjadikan kawasan Asia Tenggara sebagai kawasan yang makmur dengan pembangunan serta pengembangan ekonomi yang merata di tiap-tiap negara yang menjadi anggotanya. Dari tantangan akan terjadi persaingan dinegaranegara Asia Tenggara melalu MEA pasti masyarakat Indonesia harus mempersiapkan diri dengan meningkatkan mutu diberbagai bidang, terutama bidang sumber daya manusianya. Dalam meningkatkan sumber daya manusia juga memerlukan manajemen yang baik. ${ }^{4}$

Muhamad Mu'iz mejelaskan bahwa Kebutuhan akan manajemen sumber daya manusia yang unggul, cerdas dan berkarakter merupakan realitas yang harus dipenuhi oleh semua masyarakat dan komponen bangsa didunia ini. Memang untuk mencapai dan merealisasikan itu semua sangatlah sulit dan berat, akan tetapi tidak yang mustahil jika ada keinginan dan usaha yang baik dan sungguh-sungguh agar tercapai tujuan itu semua. Semua hal ini sangat penting, karena sesungguhnya pribadi yang unggul, cerdas dan berkarakter merupakan kebutuhan yang harus dimiliki setiap masyarakat agar bisa selamat bahagia dunia dan akhirat. ${ }^{5}$

Aktivitas kependidikan Islam ada sejak adanya manusia itu sendiri yaitu diciptakanya nabi Adam dan siti Hawa, bahkan ayat al-qur'an yang pertama kali ditrurunkan kepada Nabi Muhammad SAW adalah bukan perintah tentang sholat, puasa atau lainnya, tetapi justru perintah Iqra'(membaca, merenungkan, menelaah, meneliti atau mengkaji) atau perintah untuk mencerdaskan kehidupan manusia yang merupakan inti dari aktifitas pendidikan. Dari sinilah manusia mulai memikirkan, menelaah, dan meneliti bagaimana pelaksanaan pendidikan itu, sehingga muncullah pemikiran dan teori-teori pendidikan Islam. Sebagaimana ungkapan Abdul al-Ghani 'Ubud yang dikutip oleh Muhaimin bahwa tidak mungkin ada kegiatan pendidikan Islam dan sistem pengajaran Islam tanpa ada teori-teori atau pemikiran pendidikan Islam. ${ }^{6}$

Menurut Noer Rahmah dan Zaenal Fanani Lembaga Pendidikan Islam bisa dikategorikan sebagai lembaga industri mulia (noble industry) karena mengemban misi ganda, yaitu profit sekaligus sosial. Misi profit yang dimaksud yaitu untuk mencari keuntungan, hal ini dapat dicapai ketika efisiensi dan efektivitas dana bisa tercapai, sehingga pemasukan (income) lebih besar dari biaya operasional. Sedangkan misi sosial yaitu bertujuan untuk mewariskan dan menginternalisasikan nilai luhur. Misi kedua ini (misi sosial) dapat dicapai secara maksimal apabila lembaga pendidikan Islam tersebut memiliki Human Capital dan Social Capital yang memadai dan juga memiliki tingkat efektifitas dan efisiensi yang tinggi. Itulah alasan bahwa mengelola lembaga pendidikan Islam tidak hanya memiliki profesionalitas yang tinggi, tetapi juga misi niat suci dan mental yang kuat. Hal itu

Kepuasan berbisnis (Business Sophistication) dan Inovasi (Innovations). Oleh karena itu WEF menganggap bahwa laporan ini dapat menjadi bantuan bagi pada pengambil keputusan dalam mendesain kebijakan yang lebih baik. Sebab keputusan yang baik harus didasarkan pada kolaborasi pihak swasta dan publik. Sehingga mampu untuk menjadi upaya mengembalikan rasa percaya diri dalam menghadapi kemungkinan-kemungkinan yang terjadi karena perubahan ekonomi. Bagus Ramadhan, Tingkat Daya Saing Negara-Negara Dunia Tahun 2017-2018, Indonesia Naik Peringkat! https://www.goodnewsfromindonesia.id/2017/10/04/tingkat-daya-saingnegara-negara-dunia-tahun-2017-2018-indonesia-naik-peringkat. Diakses pada tanggal 4 Mei 2018.

${ }^{4}$ Ahmad Sahroji, Daftar Negara ASEAN dengan Peringkat Pendidikan Tertinggi, diakses dari https://news.okezone.com/read/2017/11/24/18/1820178/daftar-negara-asean-dengan-peringkat-pendidikantertinggi, pada tanggal 4 Mei 2018 pukul 19.30 WIB.

${ }^{5}$ Muhamad Mu'iz Raharjo, Manajemen Sumber Daya Manusia yang unggul, cerdas dan Berkarakter Islmai (Yogyakarta: Gava Media, 2011), h. x

${ }^{6}$ Muhaimin, et al., Manajemen Pendidikan, Aplikasinya dalam Penyusunan rencana Pengembangan Sekolah/Madrasah, \{Jakarta: Kencana, 2012), h. 3 
sama halnya mengelola noble industy yang lain, seperti rumah sakit, panti asuhan, yayasan sosial, lembaga kajian atau riset, dan lembaga swadaya masyarakat (LSM). ${ }^{7}$

Lembaga Pendidikan Ma'arif (LP Ma'arif) adalah lembaga yang mempunyai sejarah kuat dengan organisasi keagamaan terbesar di Indonesia yaitu Nahdlatul Ulama (NU). Lembaga Pendidikan Ma'arif NU merupakan lembaga yang mayoritas dihuni oleh kalangan pesantren yang konon berprinsip, yang penting berkah (tabarrukan faqad). ${ }^{8}$

Sebagaimana contoh sekolah yang peneliti tahu sekolah di bawah naungan LP Ma'arif yang berusaha memberikan kontribusi dalam mencetak generasi yang unggul untuk menghadapi era globalisasi dengan pertumbuhan ekonomi munculnya persaingan antar negara

yaitu pasar bebas atau bisa disebut dengan Masyarakat Ekonomi Asean, sekolah tersebut adalah Madrasah Ibtidaiyah ICP Nurul Ulum ${ }^{9}$, sesuai dengan pengembangan program pembelajarannya dengan tuntutan kemajuan jaman, maka dibuatlah program kelas internasional atau secara lazim disebut dengan international class program. Dalam mengembangkan program pembelajarannya, awal berdirinya MINU ICP bekerja sama dengan Unit Pelaksana Teknis Sekolah Laboratorium (UPTSL) Universitas Negeri Malang, yang MOU / kerja samanya ditanda tangani pada tahun 2008. Adapun kerja sama ini dalam bidang pengelolaan program pembelajaran, terutama yang menyangkut bidang mata pelajaran; Sains, Math, dan Eanglish. Jalinan kerja sama ini juga terhubung langsung dengan Cambridge University, Inggris. Jadi seluruh siswa yang tergabung dalam MINU ICP Bojonegoro ini nantinya akan mengikuti ujian langsung yang diselenggarakan pihak Cambridge University sebagai tes internasional dan ke Universitas Negeri Malang sebagai tes sentral. Terkait kerja sama ini MINU ICP Bojonegoro berusaha komitmen dan profesionalitas dalam pengelolaan proses pembelajarannya. ${ }^{10}$

Kemudian selain lembaga pendidikan Ma'arif NU, Muhammadiyah juga telah memberikan kontribusi yang besar dalam meningkatkan Sumber Daya Manusia Indonesia dan mewujudkan cita-cita dan tujuan pendidikan nasional, hal ini diketahui dari sejarah

\footnotetext{
${ }^{7}$ Noer Rahmah dan Zaenal Fanani, Pengantar Manajemen Pendidikan, (Malang: Madani, 2017), h. 7

8 Baharuddin dan Moh. Makin, Manajemen Pendidikan Islam ; Transformasi Menuju Sekolah atau Madrasah Unggul, (Malang: UIN Maliki Press, 2016) h. 241. Kata tabarrukan faqad adalah dua kata yaitu Tabaruk dan faqod. Tabarruk berasal dari kata al-Barakah. Arti al-Barakah adalah tambahan dan perkembangan dalam kebaikan (az-Ziyadah Wa an-Nama' Fi al-Khair). Barakah (kebaikan) dalam harta adalah ketika bertambah banyak dan digunakan dalam ketaatan kepada Allah. Barakah dalam keluarga adalah ketika anggotanya berjumlah banyak dan berakhlak mulia. Barakah dalam waktu adalah lamanya masa dan terselesaikan semua urusan dalam masa yang ada. Barakah dalam kesehatan adalah kesempurnaan dalam kesehatan itu sendiri. Barakah dalam umur adalah panjang usia dan banyak beramal baik dalam rentang usia yang panjang tersebut. Barakah dalam ilmu adalah ketika ilmu itu semakin bertambah banyak dan diamalkan serta bermanfaat untuk orang banyak. Dengan demikian barakah itu adalah laksana pundi-pundi kebaikan (Jawami' al-Khair) dan berlimpahnya nikmat yang diperoleh dari Allah. Dari penjelasan ini dipahami bahwa makna Tabarruk adalah: "Thalab Ziyadah al-Khair Min Allah". Artinya, meminta tambahan kebaikan dari Allah. Kalimat faqot (فقط) yang ma'nanya cukup (حسب)bisa diartikan hanya atau bloko (bahasa jawa) kalimat tersebut ketetapannya jadi hal (حال) dari kalimat yang diikutinya/sebelumnya, kemudian fa dalam kalimat tersebut adalah fa jaidah yang gunanya untuk menghiasi lafadz (هلين اللنظين),

${ }_{9}^{9}$ Yang dalam tulisan selanjutnya penulis sebut dengan singkatan MINU ICP

${ }^{10}$ MINU ICP Bojonegoro telah menunjukkan eksistensinya sebagai bagian dari pendidikan yang ada di Kabupaten Bojonegoro yang cukup diperhitungkan dalam kontribusinya dalam menyiapkan generasi penerus bangsa pada Era Globalisasi yang ditandai dengan pesatnya perkembangan Teknologi Informasi. Sebagai konsekwensinya, MINU ICP Bojonegoro terus berbenah diri dan mencari lompatan-lompatan cerdas dalam rangka meningkatkan kualitas Sumber Daya Manusianya, salah satunya dengan memanfaatkan sebesar-besarnya teknologi informasi dalam kegiatan pembelajaran dan kemadrasahan. Upaya merealisasi tujuan tersebut, MINU ICP Bojonegoro mencoba mengembangkan website: www.miicp-nurululum.sch.id, sebagai media dan sarana ta'aruf kepada seluruh pengguna internet. Selain itu website ini juga akan menjadi media penunjang pembelajaran berbasis teknologi. http://www.miicp-nurululum.sch.id/. Diakses pada tanggal 5 Mei 2018.
} 
berdirinya organisasi Muhammadiyah. MI Muhammadiyah 10 Klepek Sukosewu Bojonegoro $^{11}$ yang beralamatkan di jalan raya klepek RT 08 RW 02 desa Klepek Kecamatan Sukosewu Kabupaten Bojonegoro.

MIM 10 Bojonegoro memiliki visi yang ingin dicapai yaitu : "Terwujudnya Peserta Didik Yang Muslim, Berakhlaq Mulia, Cakap, Terampil dan Terpercaya Pada Diri Sendiri." Dan misinya;

1. Menegakkan ajaran Islam yang sesuai dengan ajaran Al-Qur'an dan Sunnah Nabi Muhammad SAW.

2. Membiasakan diri berakhlaq mulia dan menjauhi akhlaq tercela.

3. Menjadi uswatun hasanah di manapun dan kapanpun berada.

4. Da'wah amar ma'ruf nahi munkar.

5. Melaksanakan manajemen sekolah yang transparan, partisipatif dan akuntabel ( MBS)

Dari uraian tersebut di atas, pertanyaan yang dapat diajukan dalam penelitian ini adalah bagaimana upaya pengembangan manajemen SDM di MI ICP Nurul Ulum LP Ma'arif NU Bojonegoro dan MI Muhammadiyah 10 Bojonegoro dalam menghadapi Masyarakat Ekonomi Asean?

\section{TINJAUAN PUSTAKA}

\subsection{Manajemen Pengembangan Pendidikan Islam}

\subsubsection{Pengertian Manajemen Pengembangan Pendidikan Islam}

Untuk memudahkan pemahaman mengenai pengertian Manajemen Pengembangan Pendidikan Islam, maka perlu dijelaskan beberapa pengertian secara bahasa terlebih dahulu. Secara bahasa kata manajemen berasal dari kata managio yang berarti pengurusan atau managiare yaitu melatih dalam mengatur langkah-langkah, atau dapat juga berarti bahwa manajemen sebagai ilmu, kiat dan profesi. ${ }^{12}$

Pendapat ahli lainnya bahwa kata manajemen akar katanya berasal dari bahasa latin mano yang berarti tangan, menjadi manus, yang artinya bekerja dengan hati-hati mempergunakan dengan tangan dan kata agere artinya melakukan sesuatu sehingga menjadi managiare, yang berarti melakukan sesuatu berkali-kali dengan mempergunakan tangan. ${ }^{13}$

Manajemen menurut istilah adalah proses mengoordinasikan aktivitas-aktivitas kerja sehingga dapat selesai secara efisien dan efektif dengan melalui orang lain. ${ }^{14}$ Nanang Fatah dalam bukunya Landasan Manajemen Pendidikan memberikan batasan istilah manajemen yakni:

Manajemen merupakan proses merencana, mengorganisasi, memimpin dan mengendalikan upaya organisasi dengan segala aspeknya agar tujuan organisasi tercapai secara efektif dan efisien. ${ }^{15}$

Dari definisi ini dapat diambil pemahaman bahwa ada beberapa kata kunci dalam manajemen, yaitu: Planing (perencanaan), Organizing (mengorganisasi), Guiding (memimpin), Controling (mnegendalikan) dan the achievement of the goat (pencapaian tujuan). Dari beberapa kata kunci tersebut, dapat dikontruksi pemahaman bahwa yang dimaksud dengan menajmen adalah suatu proses perencanaan, pengorganisasian, pelaksanaan dan pengendalian ataua pengawasan dari sumber daya organisasi untuk mencapai tujuan secara efektif dan efisien. Maka dalam proses manajemen pada sebuah organisasi tidak

\footnotetext{
${ }^{11}$ Yang dalam tulisan selanjutnya penulis sebut dengan singkatan MIM 10 Bojonegoro

${ }^{12}$ Baharudin dan Moh. Makin, Manajemen Pendidikan Islam, (Malang: UIN-Maliki Malang Press, 2016), h. 68

${ }^{13}$ Donni Juni Priansa dan Sonny Suntani Setiana, Manajemen dan Supervisi Pendidikan, (Bandung: CV Pustaka Setia, 2018), h. 3

${ }^{14}$ Donni Juni Priansa dan Sonny Suntani Setiana, Manajemen dan Supervisi Pendidikan, h. 2

${ }^{15}$ Nanang Fatah, Landasan Manajemen Pendidikan, (Bandung: Remaja Rosdakarya, 2004), h. 1
} 
melalui rangkaian kegiatan atau proses di atas, sesugguhnya bukanlah sebuah kegiatan manajemen.

Terkait pendidikan Islam, menurut Muhaimin para ahli telah mengemukakan pendapatnya yang intinya ada dua macamn yaitu:

a. Pendidikan Islam merupakan aktifitas pendidikan yang diselenggarakan atau didirikan dengan hasrat dan niat untuk mewujudkan ajaran dan nilai-nilai Islam. Dalam praktiknya di Indonesia, pendidikan Islam ini setidak-tidaknya dapat dikelompokkan kedalam lima jenis, yaitu;

1) Pondok pesantren atau madrasah diniyah, yang menurut UU No. 20 Tahun 2003 tentang sitem pendidikan nasional disebut sebagai pendidikan keagamaan (Islam) formal, seperti Pondok Pesantren/Madrasah Diniyah (Ula, Wushto, 'Ulyadan Ma'had);

2) PAUD/RA, BA, TA, Madrasah, dan pendidikan lanjutannya seperti IAIN/STAIN atau Universitas Islam Negeri yang bernaung dibawah Departemen Agama;

3) Pendidikan Usia Dini/RA, BA, TA, sekolah/perguruan tinggi yang diselenggarakan oleh dan/atau berada dibawah naungan yayasan dan organisasi Islam;

4) Pelajaran Islam di sekolah/madrasah/perguruan tinggi sebagai suatu mata pelajaran atau mata kuliah, dan/atau sebagai program studi; dan

5) Pendidikan Islam dalam keluarga atau ditempat-tempat ibadah, dan/atau di forum-forum kajian keIslaman, majelis taklim, dan institusi-institusi lainnya yang sekarang sedang digalakkan oleh masyarakat, atau pendidikan (Islam) melalui jalur pendidikan nonformal, dan informal.

b. Pendidikan adalah sistem pendidikan yang dikembangkan dari dan disemangati atau dijiwai oleh ajaran dan nilai-nilai Islam. Dalam pengertian yang kedua ini, pendidikan Islam bisa mencakup;

1) Pendidik/guru/dosen, kepala sekolah/madrasah atau pimpinan perguruan tinggi dan/atau tenaga kependidikan lainnya yang melakukan dan mengembangkan aktifitas kependidikannya disemangati atau dijiwai oleh ajaran dan nilai-nilai Islam; dan

2) Komponen-komponen pendidikan lainnya, seperti tujuan, materi/bahan ajar, alat/media/sumber belajar, metode, evaluasi, lingkungan/konteks, manajemen, dan lain-lain yang disemangati atau dijawai oleh ajaran dan nilai-nilai Islam, atau yang berciri khas Islam. ${ }^{16}$

Dari kedua yang pengertian pendidikan Islam diatas, maka pengertian pertama lebih menekankan pada aspek kelembagaan dan program pendidikan Islam, dan yang kedua lebih menekankan pada aspek spirit Islam yang melekat pada aktifitas pendidikan Islam.

Dengan demikian, manajemen pendidikan Islam adalah proses pemanfaatan dari semua sumber daya yang dimiliki (umat Islam, lembaga pendidikan atau lainnya), baik berupa perangkat keras maupun perangkat lunak. Pemanfaatan tersebut dilakukan melalui kerja sama dengan orang lain secara efektif, efisien dan produktif untuk mencapai kebahagiaan dan kesejahteraan, baik di dunia maupun diakhirat. ${ }^{17}$

\footnotetext{
${ }^{16}$ Muhaimin, dkk, MANAJEMEN PENDIDIKAN Aplikasinya Dalam Menyusun Rencana Pengembangan Sekolah/Madrasah, (Jakarta: Kencana, 2012), h. 3-4

17 Dalam implementasinya manajemen pendidikan islam sudah dicontohkan oleh Nabi Muhammad SAW dalam kehidupannya dengan para sahabatnya. Nabi Muhammad SAW mengelola (manage) serta mempertahankan (mantain) kerja sama dengan sahabatnya dalam waktu yang lama. Salah satu kebiasaan Nabi adalah memberikan reward atas kreatifitas serta prestasi yang ditunjukkan sahabatnya. Ada empat pilar etika manajemen yang ada dalam islam, seperti yang dicontohkan Nabi Muhammad SAW.yaitu : Pertama,ketauhidan yang berarti memandang segala aset dari transaksi bisnis yang terjadi di dunia adalah milik Allah SWT., manusia hanya mendapat amanah untuk mengelolanya. Kedua, keadilan, artinya segala keputusan menyangkut
} 


\subsubsection{Proses Manajemen Pengembangan Pendidikan Islam}

Agar dapat menjawab tantangan perubahan yang terjadi dalam lembaga pendidikan islam, manajemen pengembangan harus dilakukan secara terus menerus. Manajemen pengembangan lembaga pendidikan islam dilaksanakan melalui POAC(Planing, Organizing, Actuating, and Controlling). Penejelasan mengenai masing-masing kegiatan manajemen tersebut akan diuraikan pada bagian berikut ini:

a. Perencanaan (planning)

Planning atau perencanaan adalah keseluruhan proses dan penentuan secara matang tentang hal-hal yang akan dikerjakan di masa akan datang dalam rangka pencapaian tujuan yang telah ditentukan. Ketika dikaitkan dengan sistem pendidikan dalam suatu organisasi kependidikan, maka perencanaan pendidikan menurut ST Vembriarto dapat didefiniskan sebagai penggunaan analisa yang bersifat rasional dan sistematis terhadap proses pengembangan pendidikan yang bertujuan untuk menjadikan pendidikan menjadi lebih efektif dan efisien dalam menanggapi kebutuhan dan tujuan murid-murid serta masyarakat.

Adapun kegunaan perencanaan adalah sebagai berikut:

1) Karena perencanaan meliputi usaha untuk memetapkan tujuan atau memformulasikan tujuan yang dipilih untuk dicapai, maka perencanaan haruslah bisa membedakan point pertama yang akan dilaksanakan terlebih dahulu.

2) Dengan adanya perencanaan maka memungkinkan kita mengetahui tujuan-tujuan yang kan kita capai.

3) Dapat memudahkan kegiatan untuk mengidentifikasikan hambatan-hambatan yang akan mungkin timbul dalam usaha mencapai tujuan.

Dalam upaya meningkatkan efektivitas dan efisiensi suatu organisasi pendidikan, perhitungan-perhitungan secara teliti sudah harus dilakukan pada vase perencanaan pendidikan. Untuk memenuhi tuntutan tersebut, maka berlaku prinsip-prinsip perencanaan, yaitu :

1) Perencanaan harus bersifat komprehensif .

2) Perencanaan pendidikan harus bersifat integral.

3) Perencanaan pendidikan harus memperhatikan aspekaspek kualitatif.

4) Perencanaan pendidikan harus merupakan rencana jangka panjang dan kontinyu.

5) Perencanaan pendidikan harus didasarkan pada efisiensi.

6) Perencanaan pendidikan harus memperhitungkan semua sumber-sumber yang ada atau yang dapat diadakan.

7) Perencanaan pendidikan harus dibantu oleh organisasi administrasi yang efisien dan data yang dapat diandalkan.

Dalam proses perencanaan terhadap program pendidikan yang akan dilaksanakan, khususnya dalam lembaga pendidikan Islam, maka prinsip perencanaan harus mencerminkan terhadap nilai-nilai islami yang bersumberkan pada al-Qur'an dan al-Hadits. Dalam hal perencanaan ini al-Qur'an mengajarkan kepada manusia

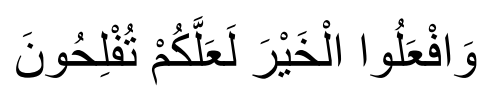

Artinya : Dan berbuatlah kebajikan supaya kamu mendapatkan keberuntungan (AlHajj : 77)

transaksi dan interaksi dengan orang lain didasarkan pada kesepakatan kerja yang dilandasi oleh akad saling setuju dengan sistem profitt and lost sharing. Ketiga, kehendak bebas, artinya manajemen islam mempersilahkan manusia untuk menumpahkan segala kreatifitas dalam melakukan transaksi dan interaksi sosial sepanjang memenuhi asas hukum yang baik dan benar. Keempat, pertanggung jawaban, artinya semua keputusan seorang pimpinan harus dipertanggungjawabkan oleh yang bersangkutan. KH.U.Saefullah, Manajemen Pendidikan Islam, h.49-50 
Selain ayat tersebut, terdapat pula ayat yang menganjurkan kepada para manejer atau pemimpin untuk menentukan sikap dalam proses perencanaan pendidikan. yaitu dalam alQur'an surat an-Nahl ayat 90:

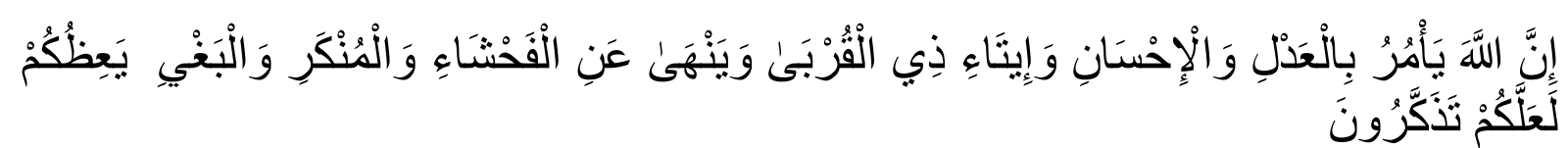

Artinya : Sesungguhnya Allah menyuruh kamu berlaku adil dan berbuat kebajikan atau kebaikan, memberi kepada kaum kerabat dan Allah melarang perbuatan yang keji, mungkar dan permusuhan. Dia memberi pelajaran kepadamu agar kamu dapat mengambil pelajaran (Qs. An-Nahl: 90).

Ayat tersebut merupakan suatu hal yang sangat prinsipil yang tidak boleh ditawar dalam proses perencanaan pendidikan, agar tujuan yang ingin dicapai dapat tercapai dengan sempurna. Disamping itu pula, intisari ayat tersebut merupakan suatu "pembeda" antara manajemen secara umum dengan manajemen dalam perspektif Islam yang sarat dengan nilai.

b. Pengorganisasian (organizing)

Organisasi adalah sistem kerja sama sekelompok orang untuk mencapai tujuan bersama. Langkah pertama dalam pengorganisasian diwujudkan melalui perencanaan dengan menetapkan bidang-bidang atau fungsi-fungsi yang termasuk ruang lingkup kegiatan yang akan diselenggarakan oleh suatu kelompok kerjasama tertentu. Keseluruhan pembidangan itu sebagai suatu kesatuan merupakan total sistem yang bergerak ke arah satu tujuan. Dengan demikian, setiap pembidangan kerja dapat ditempatkan sebagai sub sistem yang mengemban sejumlah tugas yang sejenis sebagai bagian dari keseluruhan kegiatan yang diemban oleh kelompok-kelompok kerjasama tersebut.

Wujud dari pelaksanaan organizing ini adalah tampaknya kesatuan yang utuh, kekompakan, kesetiakawanan dan terciptanya mekanisme yang sehat, sehingga kegiatan lancar, stabil dan mudah mencapai tujuan yang ditetapkan. Proses organizing yang menekankan pentingnnya tercipta kesatuan dalam segala tindakan, dalam hal ini al-Qur'an telah menyebutkan betapa pentingnya tindakan kesatuan yang utuh, murni dan bulat dalam suatu organisasi. Firman Allah dalam surat Ali Imran: 103,

Al-Qur'an memberikan petunjuk agar dalam suatu wadah, tempat, persaudaraan, ikatan, organisasi, kelompok, janganlah timbul pertentangan, perselisihan, perscekcokan yang mengakibatkan hancurnya kesatuan, runtuhnya mekanisme kepemimpinan yang telah dibina. Firman Allah:

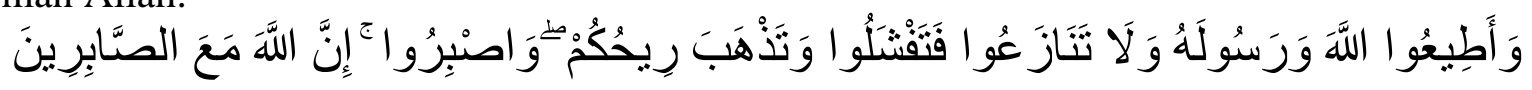

Artinya : Dan taatilah Allah dan RasulNya, jangalah kamu berbantahbantahan yang menyebabkan kamu menjadi gentar, hilang kekuatanmu, dan bersabarlah, sesungguhnya Allah beserta orang-orang yang sabar (Al-Anfal : 46) ${ }^{18}$

c. Penggerakan (actuating)

Fungsi actuating merupakan bagian dari proses kelompok atau organisasi yang tidak dapat dipisahkan. Adapun istilah yang dapat dikelompokkan ke dalam fungsi ini adalah directing commanding, leading dan coordinating.

Karena tindakan actuating sebagaimana tersebut di atas, maka proses ini juga memberikan motivating, untuk memberikan penggerakan dan kesadaran terhadap dasar dari pada pekerjaan yang mereka lakukan, yaitu menuju tujuan yang telah ditetapkan, disertai

${ }^{18}$ Dalam tafsirnya M. Quraish Shihab menjelaskan; Taatilah Allah dengan menepati segala perintah dan larangan-Nya. Tinggalkanlah perselisihan dan pertikaian yang membuat kalian tercerai berai dan lemah. Bersabarlah dalam menghadapi segala kesulitan dan rintangan dalam peperangan. Sesungguhnya Allah bersama orang-orang yang sabar dengan memberi dukungan, peneguhan dan belaan yang baik. . M.Quraish Shihab, Tafsir al-Mishbah (Jakarta:Lentera Hati, 2002). 
dengan memberi motivasi-motivasi baru, bimbingan atau pengarahan, sehingga mereka bisa menyadari dan timbul kemauan untuk bekerja dengan tekun dan baik.

Bimbingan berarti memelihara, menjaga dan memajukan organisasi melalui setiap personal, baik secara struktural maupun fungsional, agar setiap kegiatannya tidak terlepas dari usaha mencapai tujuan. Dalam realitasnya, kegiatan bimbingan dapat berbentuk sebagai berikut :

1) Memberikan dan menjelaskan perintah.

2) Memberikan petunjuk melaksanakan kegiatan.

3) Memberikan kesempatan meningkatkan penge-tahuan, keterampilan/kecakapan dan keahlian agar lebih efektif dalam melaksanakan berbagai kegiatan organisasi.

4) Memberikan kesempatan ikut serta menyumbangkan tenaga dna fikiran untuk memajukan organisasi berdasarkan inisiatif dan kreativitas masing-masing.

5) Memberikan koreksi agar setiap personal melakukan tugas-tugasnya secara efisien.

Al-Qur'an dalam hal ini telah memberikan pedoman dasar terhadap proses pembimbingan, pengarahan ataupun memberikan peringatan dalam bentuk actuating ini. Allah berfirman :

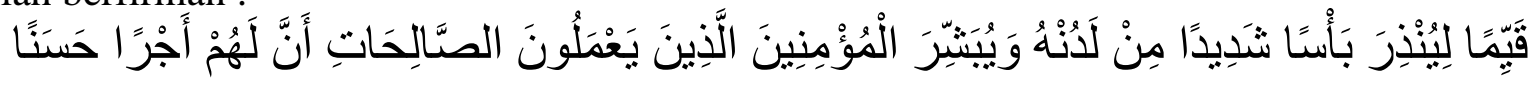

Artinya: Sebagai bimbingan yang lurus, untuk memperingatkan siksaan yang sangat pedih dari sisi Allah dan memberi berita gembira kepada orangorang yang beriman, yang mengerjakan amal saleh, bahwa mereka akan mendapat pembalasan yang baik, (QS. al-Kahfi: 2)

Actuating juga berarti mengelola lingkungan organisasi yang melibatkan lingkungan dan orang lain, tentunya dengan tata cara yang baik pula. Maka firman Allah mengatakan:

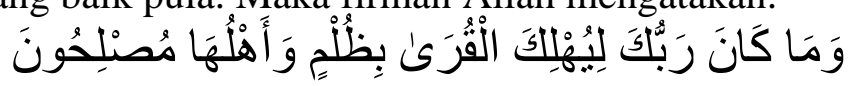

Artinya: "Dan Tuhanmu sekali-kali tidak akan membinasakan negerinegeri secara zalim, sedang penduduknya orang-orang yang berbuat kebaikan." (Qs. Hud: 117) ${ }^{19}$

Faktor membimbing dan memberikan peringatan sebagai hal penunjang demi suksesnya rencana, sebab jika hal itu diabaikan akan memberikan pengaruh yang kurang baik terhadap kelangsungan suatu roda organisasi dan lain-lainnya.

Proses actuating adalah memberikan perintah, petunjuk, pedoman dan nasehat serta keterampilan dalam berkomunikasi. Actuating merupakan inti dari manajemen yang menggerakkan untuk mencapai hasil. Sedangkan inti dari actuating adalah leading, harus menentukan prinsip-prinspi efisiensi, komunikasi yang baik dan prinsip menjawab pertanyaan.

\section{d. Evaluasi/Controlling}

Evaluasi dalam konteks manajemen adalah proses untuk memastikan bahwa aktivitas yang dilaksanakan benar sesuai apa tidak dengan perencanaan sebelumnya. Evaluasi dalam manajemen pendidikan Islam ini mempunyai dua batasan pertama; evaluasi tersebut merupakan proses/kegiatan untuk menentukan kemajuan pendidikan dibandingkan dengan tujuan yang telah ditentukan, kedua; evaluasi yang dimaksud adalah usaha untuk memperoleh informasi berupa umpan balik (feed back) dari kegiatan yang telah dilakukan. .

Controlling itu penting sebab merupakan jembatan terakhir dalam rantai fungsional kegiatan-kegiatan manajemen. Pengendalian merupakan salah satu cara para manajer untuk mengetahui apakah tujuan-tujuan organisasi itu tercapai atau tidak dan mengapa terpai atau tidak tercapai. Selain itu controlling adalah sebagai konsep pengendalan, pemantau efektifitas

${ }^{19}$ Bukan merupakan suatu ketentuan dan keadilan Allah di alam ini, untuk menganiaya penduduk suatu negeri dengan membinasakan mereka, padahal mereka berpegang teguh pada kebenaran dan melaksanakan segala kebaikan secara konsisten serta mengerjakan segala yang membawa kemaslahatan bagi diri mereka dan orang lain. 
dari perencanaan, pengorganisasian, dan kepemim-pinan serta pengambilan perbaikan pada saat dibutuhkan.

Adapun ayat al-Qur ${ }^{\text {ee }}$ an yang berkaitan dengan evaluasi/controllilg sebagai berikut:

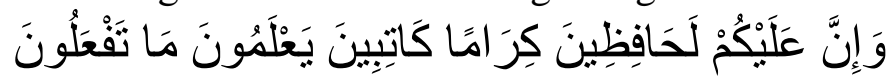

Artinya: "padahal ssungguhnya bagi kamu ada malaikat yang mengawasi pekerjaanmu (10) yang mulia disisi Allah dan yang mencatat pekerjaan itu (11) mereka mengetahui apa yang kamu kerjakan” (12) (Al-Qur"an 82:10-12).

Agar kegiatan pengawasan dapat berjalan dengan baik, maka kemendiknas mengemukan beberapa poin penting mengenai pelaksanaan kegiatan pengawasan, yaitu:

1) Pengawasan bersifat membimbing dan membantu mengatasi kesulitan dan bukan mencari kesalahan.

2) Bantuan dan bimbingan diberikan secara tidak langsung. Artinya diupayakan agar yang bersangkutan merasa mampu mengatasi sendiri masalahnya.

3) Balikan atau saran seharusnya segera diberikan dengan tujuan agar yang bersangkutan segera memahami.

4) Pengawasan dilakukan secara periodik, artinya tidak menunggu sampai terjadi hambatan.

5) Pengawasan dilaksanakan dalam suasana kemitraan. ${ }^{20}$

\subsection{Manajemen Sumber Daya Manusia}

\subsubsection{Pengertian Manajemen Sumber Daya Manusia (MSDM)}

a. Sumber Daya Manusia (SDM)

Istilah Manajemen Sumber Daya Manusia (MSDM) atau dikenal dengan Human Resource Management(HRM) adalah istilah modern yang mengemuka dan diterima luas pada tahun 1969 saat perhimpunan Amerika untuk Administrasi personalia (American Society for public Administrasion atau ASPA) berubah nama menjadi perhimpunan untuk MSDM (Society for Human Resource Management). Menurut Ismail sebagaimana dikutip oleh Muiz, pengertian manajemen sumber daya manusia pada dasarnya dibangun oleh dua konsep yakni konsep mengenai (management) dan konsep mengenai sumber daya manusia (human resources) Masing-masing konstruksi konsep tersebut secara resiprokal berperan dalam membangun pengertian tentang MSDM secara utuh. ${ }^{21}$

Adapun pengertian sumber daya manusia menurut Byars dan Rue sebagaimana dikutip oleh Muiz adalah desain aktivitas yang mencakup pengadaan dan pengkoordinasian sumber daya manusia menurut Jakob dan Schuler sebagaimana dikutip oleh Muiz adalah orang yang berbakat dan semangat tinggi yang tersedia bagi organisasi sebagai kontributor potensial untuk menciptakan dan merealisasikan tujuan, misi serta visi organisasi, ini sebagaimana yang disebutkan Al Fajar dan Tri Heru sebagaimana yang dikutip oleh Muiz. ${ }^{22}$

Manajemen sumber daya manusia menurut Sedarmayanti sebagaimana dikutip oleh Muiz, adalah kebijakan dan praktik menentukan aspek "manusia" atau sumber daya manusia dalam posisi manajemen. Sedangkan tujuan sumber daya manusia secara umum adalah memastikan bahwa organisasi mampu mencapai keberhasilan melalui orang. Oleh karena itu, menurut penulis, keberhasilan akan konsep manajemen sumber daya manusia sangat tergantung dari kemampuan dan keunggulan dari pelakunya (orang-orang) yang terlibat atau ada di dalamnya. ${ }^{23}$

\footnotetext{
${ }^{20}$ H. Baharudin dan H. Makin, Manajemen Pendidikan Islam, h. 171

${ }^{21}$ Muhammad Mu'iz Raharjo, Manajemen Sumber Daya Manusia yang Unggul, Cerdas \& Berkarakter Islami (Yogyakarta: Gava Media, 2011). h. xi

${ }^{22}$ Muhammad Mu'iz Raharjo, Manajemen Sumber Daya Manusia, h. xi

${ }^{23}$ Muhammad Mu'iz Raharjo, Manajemen Sumber Daya Manusia. h. xii
} 
Berdasarkan definisi di atas, penulis mendefinisikan SDM dengan keseluruhan penentuan dan pelaksanaan berbagai aktivitas, policy, dan program kerja yang bertujuan untuk mendapatkan tenaga kerja, pengembangan, dan pemeliharaan dalam usaha meningkatkan dukungannya terhadap peningkatan efektivitas organisasi dengan cara yang secara etis dan sosial dapat dipertanggungjawabkan.

1. Tujuan dan Kegiatan MSDM

Apa yang dilakukan organisasi dalam upaya mencapai tujuan tersebut dan mengapa itu harus dilakukan, berkaitan dengan kegiatan atau aktivitas manajemen sumber daya manusia, akan digambarkan secara umum sebagai berikut. yaitu:

Kegiatan atau aktivitas MSDM secara umum dapat dikategorikan menjadi empat,

a) Persiapan dan Pengadaan

Kegiatan persiapan dan pengadaan meliputi banyak kegiatan, di antaranya adalah kegiatan analisis jabatan, yaitu kegiatan untuk mengetahui jabatan-jabatan yang ada dalam organisasi beserta tugas-tugas yang dilakukan dan persyaratan yang harus dimiliki oleh pemegang jabatan tersebut dan lingkungan kerja di mana aktivitas tersebut dilakukan.

b) Pengembangan dan Penilaian

Setelah bekerja secara berkala, mereka harus melakukan pelatihan-pelatihan. Hal ini bisa meningkatkan produktivitas kerja pegawai dan menjaga terjadinya keusangan kemampuan pegawai akibat perubahan-perubahan yang terjadi dalam lingkungan kerja. Selanjutnya dilakukan penilaian yang bertujuan untuk melihat apakah unjuk kerja pegawai sesuai dengan yang diharapkan, dan memberikan umpan balik untuk meningkatkan kemampuan dan kinerja.

c) Pengkompensasian dan perlindungan

Untuk mempertahankan dan memelihara semangat kerja dan motivasi, para pegawai diberi kompensasi dan beberapa kenikmatan atau keuntungan lainnya dalam bentuk programprogram kesejahtraan. Hal ini disebabkan pegawai menginginkan balas jasa yang layak sebagai konsekuensi pelaksanaan pekerjaan.

d) Hubungan-hubungan kepegawaian

Kegiatan untuk meningkatkan hubungan antar pegawai agar selalu solid dan harmonis perlu mengadakan kegiatan yang bisa menumbuhkan rasa memiliki terhadap perusahaan, dan terjalin silaturahim antar pegawai yang baik sehingga dalam bekerjanya selalu semangat dan nyaman sehingga terjalin hubungan emosional antar pegawai. Kegiatan-kegiatan tersebut misalnya mengadakan out bound dan tour ke tempat-tempat wisata dll.

2. Faktor-faktor Manajemen SDM

Faktor-faktor yang dapat mempengaruhi pengembangan SDM adalah sebagai berikut;

(1) Faktor hukum dan politik, (2) Faktor ekonomi, dan (3) Faktor budaya.

a) Faktor hukum dan politik; sifat dan stabilitas sistem politik berbeda antara satu negara dengan negara lain, Indonesia termasuk dalam sistem politik yang tidak stabil, hal ini akan mempengaruhi arah politik kebijakan dalam pendidikan, dampak lebih lanjut kebijakan sekolah akan mempengaruhi pola manajemen lembaga (sekolah/madrasah).

b) Faktor ekonomi; ekonomi sangat berhubungan dengan permasalahan politik, hukum dan budaya. Sistem perekonomian sebuah negara akan mempengaruhi budaya konsumsi, sistem sosial dan lain sebagai, termasuk jika kita kaitkan dalam dunia pendidikan adalah mempengaruhi inovasi pendidikan yang hal ini membutuhkan biaya.

c) Faktor budaya; pengaruh kebudayaan menimbulkan persoalan penting dalam manajemen SDM. Kebudayaan terdiri atas kekuatan sosial yang mempengaruhi nilai-nilai kenyakinan 
dan tindakan-tindakan seseorang maupun kelompok. Dimensi kebudayaan juga mempengaruhi pola komunikasi, strata sosial dan orientasi masa depan. ${ }^{24}$

3. Fungsi-fungsi Manajemen Sumber Daya Manusia

Di samping menjalankan fungsi manajemen, seorang manajer SDM juga harus melakukan pengawasan terhadap orang lain yang diberi tanggung jawab untuk melaksanakan tugas operasional. Dengan perkataan lain seorang manajer juga mempunyai fungsi operasional. Oleh sebab itu secara garis besar, fungsi manajer itu dikelompokkan menjadi dua, yakni:

a) Fungsi-fungsi manajerial, yang mencakup:

1) Perencanaan (Planning)

Semua orang menyadari bahwa perencanaan merupakan bagian terpenting dalam proses manajemen. Oleh karena itu perencanaan ini menyita waktu banyak dalam proses manajemen. Untuk manajer sumber daya manusia, perencanaan berarti penentuan program karyawan (sumber daya manusia) dalam rangka membantu tercapainya sasaran atau tujuan organisasi itu.

2) Pengorganisasian (Organizing)

Apabila serangkaian kegiatan telah disusun dalam rangka mencapai tujuan organisasi, maka untuk pelaksanaan atau implementasi kegiatan tersebut harus diorganisasikan. Organisasi sebagai alat untuk mencapai tujuan secara efektif, oleh sebab itu dalam fungsi organisasi harus terlihat pembagian tugas dan tanggung jawab orangorang atau karyawan yang akan melakukan kegiatan masing-masing.

3) Pengarahan (Directing)

Agar pelaksanaan kegiatan tersebut dapat berjalan dengan efektif diperlukan arahan (directing) dari manajer. Dalam suatu organisasi yang besar pengarahan ini tidak mungkin dilakukan oleh manajer itu sendiri, melainkan didelegasikan kepada orang lain yang diberi wewenang untuk itu.

4) Pengendalian (Controlling)

Fungsi pengendalian adalah untuk mengatur kegiatan, agar kegiatan-kegiatan organisasi itu dapat berjalan sesuai dengan rencana. Di samping itu pengendalian juga dimaksudkan untuk mencari jalan keluar atau pemecahan apabila terjadi hambatan pelaksanaan kegiatan. Empat kegiatan di atas adalah merupakan fungsi dasar dan umum bagi seseorang manajer.

b) Fungsi-fungsi operasional, yang mencakup:

1) Pengadaan Tenaga (Recruitment)

Fungsi rekruitmen seorang manajer SDM bertujuan untuk memperoleh jenis dan jumlah tenaga atau SDM yang tepat, sesuai dengan kemampuan yang dibutuhkan oleh unit-unit kerja yang bersangkutan. Penentuan SDM yang akan dipilih harus benar-benar yang diperlukan, bukan karena ada tenaga tersedia. Oleh sebab itu sistem rekrutmen yang mencakup seleksi harus terlebih dahulu dikembangkan secara matang.

2) Pengembangan (Development)

Tenaga atau sumber daya yang telah diperoleh suatu organisasi, perlu pengembangan sampai pada taraf tertentu sesuai dengan pengembangan organisasi itu. Pengembangan sumber daya ini penting searah dengan pengembangan organisasi. Apabila organisasi itu ingin berkembang seyogianya diikuti oleh pengembangan sumber daya manusia. Pengembangan SDM ini dapat dilaksanakan melalui pendidikan dan pelatihan yang berkesinambungan.

3) Kompensasi (Compensation)

\footnotetext{
${ }^{24}$ Robert L Matis-John H. Jackson. Op.Cit. h.7-13
} 
Kompensasi adalah merupakan fungsi manajemen yang sangat penting. Melalui fungsi ini organisasi memberikan balas jasa yang memadai dan layak kepada karyawan. Hal ini wajar karena karyawan sebagai SDM organisasi tersebut telah memberikan jasanya yang besar terhadap pencapaian tujuan organisasi. Dari hasil-hasil penelitian, meskipun kompensasi bukan hanya berupa materi atau uang, namun bentuk gaji sangat penting untuk meningkatkan hasil kerja.

4) Integrasi (Integration)

Integrasi adalah kegiatan manajemen yang bertujuan untuk rekonsiliasi kepentingan-kepentingan karyawan dalam organisasi itu. Telah disadari bersama bahwa dalam pelaksanaan kegiatan organisasi sering terjadi benturan kepentingan di antara karyawan atau antara karyawan dengan manajer. Untuk itulah pentingnya fungsi integrasi ini agar diperoleh kesepakatan kembali dalam pelaksanaan kegiatan organisasi.

\section{5) Pemeliharaan (Maintenance)}

Kemampuan-kemampuan sumber daya manusia yang telah dimiliki oleh suatu organisasi perlu dipelihara (maintenance). Karena kemampuan tersebut adalah merupakan aset yang penting bagi terlaksananya tugas dan tercapainya tujuan organisasi. Fungsi pemeliharaan kemampuan SDM ini termasuk juga jaminan kesehatan dan keselamatan kerja karyawan, agar karyawan betah dalam organisasi tersebut.

6) Pemisahan (Separation)

Seorang karyawan tidak mungkin akan selalu bekerja pada organisasi tertentu. Pada suatu ketika paling tidak mereka harus memutuskan hubungan kerja dengan cara pensiun. Untuk itu maka tenaga kerja atau karyawan tersebut harus kembali ke masyarakat. Organisasi harus bertanggung jawab dalam memutuskan hubungan kerja ini sesuai dengan ketentuan-ketentuan yang berlaku, dan menjamin warga masyarakat yang dikembalikan itu berada dalam keadaan yang sebaik mungkin. Seorang manajer sumber daya manusia harus melaksanakan fungsi ini dengan baik. ${ }^{25}$

\section{Model Manajemen Sumber Daya Manusia}

Manajemen sumber daya manusia adalah suatu sistem yang terdiri dari berbagai macam kegiatan. Kegiatan-kegiatan tersebut tidak berdiri sendiri. Melainkan di antara satu dengan yang lainnya saling mempengaruhi dan saling memerlukan. Dengan kata lain sistem manajemen sumber daya manusia itu terdiri dari beberapa subsistem yang saling berhubungan.

Model sistem manajemen sumber daya manusia ini dapat diilustrasikan sebagai berikut, ${ }^{26}$

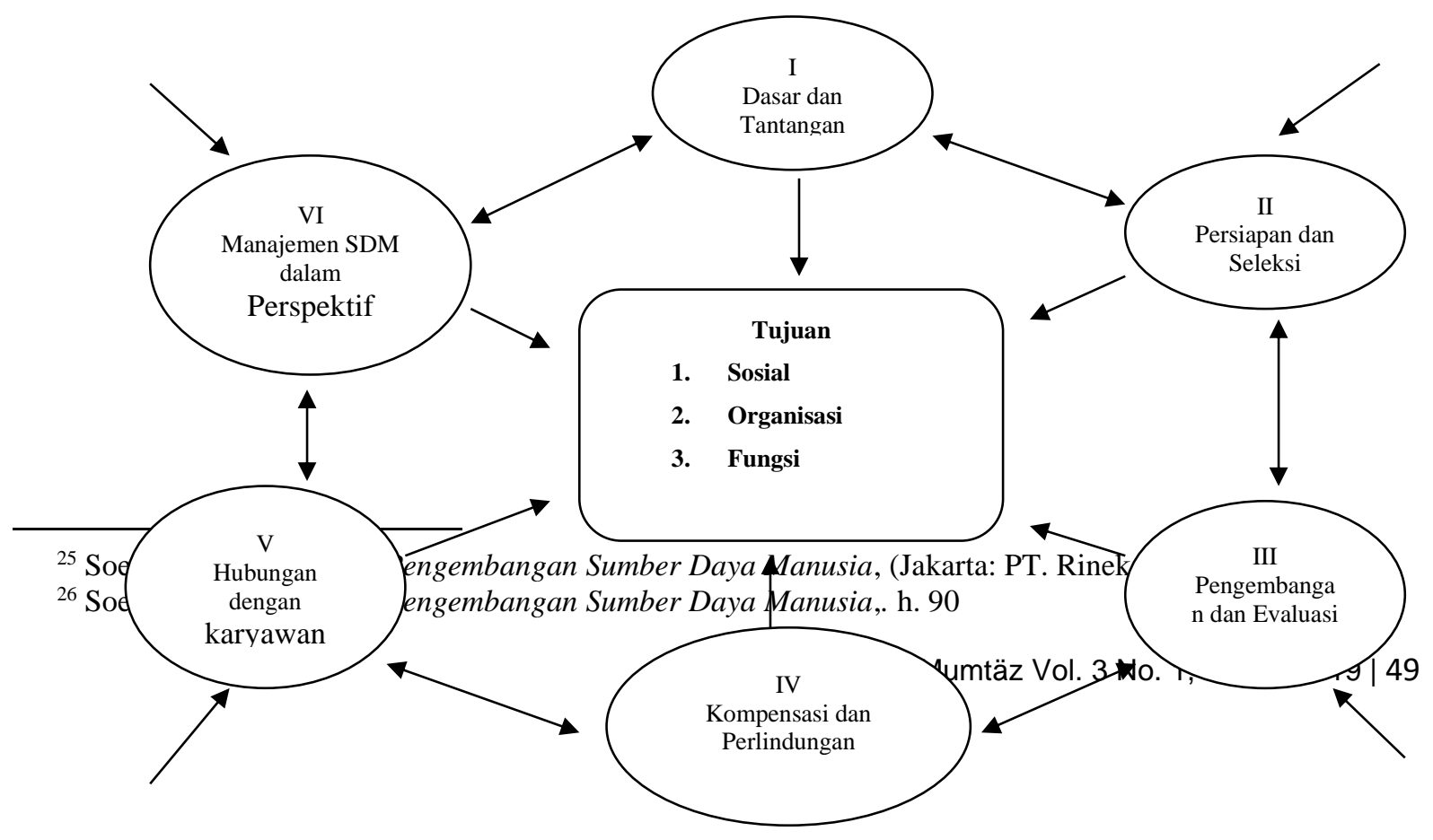


$\longleftrightarrow$ Umpan balik diantara kegiatan dan tujuan

$\longrightarrow \quad$ Tantangan-tantangan dari luar terhadap kegiatan sumber daya manusia

Dari gambar tersebut di atas tampak bahwa setiap sub sistem akan berpengaruh dan mempengaruhi sub sistem yang lain. Misalnya, tantangantantangan yang dihadapi oleh bagian manajemen sumber daya manusia akan mempengaruhi penyiapan dan seleksi, dan selanjutnya sistem seleksi ini mempengaruhi subsistem pengembangan selanjutnya. Di samping itu, setiap sub sistem dalam sistem manajemen sumber daya manusia tersebut akan dipengaruhi oleh lingkungan di mana organisasi tersebut itu berada.

Perlu ditambahkan di sini bahwa sistem manajemen sumber daya model ini adalah sistem terbuka. Dalam sistem ini maka setiap sub sistem dan orang-orang di dalam sistem dan sub sistem ini menerima pengaruh dan merespons perubahanperubahan dan tantangan-tantangan dari luar organisasi itu. Dalam sistem terbuka ini tantangan-tantangan dari luar adalah merupakan input juga dalam proses transformasi.

\section{Organisasi Manajemen Sumber Daya Manusia}

Organisasi manajemen sumber daya manusia adalah merupakan bagian dari organisasi secara keseluruhan. Besar kecilnya organisasi manajemen sumber daya manusia akan tergantung dari besar kecilnya organisasi yang bersangkutan. Oleh sebab itu nama organisasi manajemen sumber daya manusia itu tiap organisasi berbeda-beda, ada yang menamakan biro, bagian, departemen, seksi, dan sebagainya. ${ }^{27}$

Berdasarkan penjelasan di atas, penulis dapat simpulkan organisasi manajemen SDM itu menjadi bagian dari organisasi secara keseluruhan besar kecilnya sebuah organisasi manajemen bergantung dari jumlah kecilnya organisasi di dalamnya. Adapun penamaan organisasi manajemen tiap-tiap organisasi berbeda-beda penamaannya ada yang memberi nama biro, bagian, seksi, departemen dan lain sebagainya.

\section{Penilaian Efektivitas Sumber Daya Manusia}

Untuk mengetahui manfaat sumber daya manusia bagi kemajuan dan keberhasilan organisasi secara keseluruhan, perlu adanya penilaian terhadap hasil kegiatan tersebut. Selanjutnya untuk penilaian manajemen sumber daya manusia ini diperlukan kriteria, yakni kriteria manfaat dan kriteria biaya. ${ }^{28}$

a. Kriteria manfaat (benefit criteria):

Untuk kriteria ini digunakan indikator produktivitas dan kualitas kehidupan kerja. Produktivitas menggunakan indikator.

${ }^{27}$ Soekidjo Notoatmodjo, Pengembangan Sumber Daya Manusia, h. 92

${ }^{28}$ Soekidjo Notoatmodjo, Pengembangan Sumber Daya Manusia, h. 94 
1) Peningkatan prestasi kerja,

2) Penurunan absensi karyawan,

3) Penurunan rotasi tenaga kerja.

Sedangkan indikator kualitas kerja antara lain:

1) Peningkatan partisipasi kerja,

2) Peningkatan kepuasan kerja,

3) penurunan stress,

4) Penurunan jumlah kecelakaan kerja,

5) Penurunan jumlah karyawan sakit.

b. Kriteria biaya (cost criteria):

Untuk manajemen sumber daya manusia berbagai indikator yang digunakan untuk membiayai suatu kegiatan yang berkaitan dengan pengelolaan sumber daya manusia. Apabila kriteria manfaat pada umumnya untuk diterapkan pada kegiatan personalia secara keseluruhan, maka kriteria biaya adalah lebih spesifik untuk setiap kegiatan. Misalnya kriteria biaya yang sesuai untuk kegiatan keamanan dan kesehatan dalam bentuk biaya pelatihan, supervisi, pembelian peralatan, penanganan, pemindahan sumber bahaya, dan sebagainya. ${ }^{29}$

Setelah kriteria biaya dan kriteria manfaat relevan dan sesuai dengan yang ditentukan, berbagai biaya dan manfaat tersebut dibandingkan. Pembandingan tersebut sebaiknya dilakukan dalam bentuk nilai uang.

\subsection{Masyarakat Ekonomi ASEAN}

\subsubsection{Pengertian Masyarakat Ekonomi ASEAN}

Kerjasama jika dilihat dari tujuannya adalah untuk mencapai sebuah hasil yang lebih besar. Hal tersebut berlaku pula dengan kerjasama yang terjalin antar negara, yaitu untuk mencapai hasil yang jauh lebih memberikan banyak manfaat baik dalam aspek ekonomi, politik, sosial budaya, ilmu pengetahuan dan teknologi. Akan tetapi setiap negara sadar akan kekurangan yang dimilikinya baik dalam keterbatasan sumber daya manusia maupun sumber daya energi, sehingga memaksa untuk bergantung pada negara lain melalui sebuah kerjasama internasional.

Secara umum Mayarakat Ekonomi ASEAN (MEA) ialah sebuah bentuk agenda integrasi ekonomi negara-negara ASEAN yang tujuanya meminimalisir hambatan hambatan dalam melakukan kegiatan ekonomi (perdagangan barang jassa dan investasi) lintas negara. Dibentuknya ASEAN merubah peta kekuatan ekonomi dunia yang sebelumnya dunia hanya berpusat pada amerika dan cina. Melalui ASEAN banyak kebijakan dan kesepakatan yang muncul melalui ASEAN yang kemudian membawa perubahan terhadap pertumbuhan ekonomi asia dan yang sering sekali dibicarakan sampai saat ini yakni MEA (masyarakat ekonomi asia). ${ }^{30}$

Dengan adanya MEA diharapkan negara-negara Asia tenggara bisa tumbuh kembang diberbagai sektor seperti ekonomi, pendidikan dan kesehatan, bahkan hubungan politik diplomatik. Serta dapat menjadi momentum untuk memotifasi upaya peningkatan SDM rakyat indonesia dalam menghadapi era globalisasi atau pasar bebas.

Lewat KTT di Malaysia di tahun 1997 akan dibentuknya MEA, saat itu gagasan muncul karena sesuai dengan keinginan terwujudnya kawasan baru yang memiliki

${ }^{29}$ Soekidjo Notoatmodjo, Pengembangan Sumber Daya Manusia, h.94-95

${ }^{30}$ Farkhan, Pengertian Masyarakat Ekonomi ASEAN : https://khanfarkhan.com/pengertian-tujuan-danciri-ciri-mea-masyarakat-ekonomi-asean/, diakases pada tanggal 21 Januari 2019. 
kemakmuran, kestabilan politik dan pertumbuhan ekonomi yang bersaing. Selanjutnya gagasan ini terus menguat sampai dibentuk kembali KTT di Bali pada bulan Oktober 2003 yang kemudian menghasilkan kesepakatan MEA untuk diwujudkan di tahun $2020^{31}$

Terbentuknya ASEAN merubah peta kekuatan ekonomi dunia yang sebelumnya dunia hanya berpusat pada Amerika dan China. Melalui ASEAN banyak kebijakan dan kesepakatan yang muncul membawa perubahan terhadap pertumbuhan ekonomi Asia, dan yang paling banyak dibicarakan hingga saat ini adalah MEA (Masyarakat Ekonomi Asia). Gagasan terbentuknya MEA telah direncanakan pada tahun 1997 melalui KTT di Malaysia, saat itu gagasan muncul karena didasari adanya keinginan terwujudnya kawasan baru yang memiliki kemakmuran, kestabilan politik, dan pertumbuhan ekonomi yang bersaing. Kemudian gagasan ini terus menguat hingga diadakan kembali KTT di Bali pada bulan Oktober 2003 yang menghasilkan kesepakatan MEA untuk terwujud di tahun 2020. Perubahan gelombang ekonomi yang tidak menentu yang terjadi pada Eropa dan Amerika, menjadi pemicu terhadap perubahan pelaksanaan MEA. MEA yang awalnya direncanakan di tahun 2020 mengalami perubahan setelah melalui kesepakatan anggota, yaitu pelaksanaannya dipercepat pada tahun $2015 .{ }^{32}$

Masyarakat Ekonomi ASEAN (MEA) atau ASEAN Economic Community (AEC) merupakan sebuah sistem yang menuju sebuah kesepakatan dalam mengintegrasikan ekonomi antar negara ASEAN. Dari namanya jelas sekali bahwa fokus dari MEA ini adalah bidang ekonomi. Ekonomi memiliki peran penting bagi kemajuan suatu bangsa, dan MEA adalah media yang tepat untuk mampu bersaing dengan ekonomi Amerika, Eropa, dan China. Berkaitan dengan perluasan ekonomi, MEA telah merencanakan peta ekonomi baru yang menguntungkan untuk negara-negara ASEAN yaitu dengan dibukanya pasar perdagangan bebas. Dengan dibukanya perdagangan bebas, maka hal ini akan meminimalkan kesulitankesulitan yang selama ini menjadi penghalang untuk kegiatan ekspor impor seperti peraturan bea cukai. ${ }^{33}$

Di Indonesia MEA telah diberlakukan mulai Desember 2015, meski diawal memunculkan banyak kekhawatiran bagi sebagian orang akan daya saing yang dimiliki oleh tenaga kerja dan masyarakat, namun hal tersebut tidak menjadi sebuah hambatan, karena pada dasarnya MEA adalah peluang bagi suatu negara untuk lebih produktif dalam kegiatan ekonomi dan bagi masyarakat atau pelaku usaha merupakan sebuah moment yang tepat untuk memperkenalkan brand dalam negeri ke dunia internasional. Salah satu langkah indonesia untuk menghadapi MEA adalah menumbuhkan sektor-sektor UKM, semenjak sebelum dan sesudah MEA diberlakukan, pemerintah sangat gencar sekali memberikan dorongan dalam meningkatkan peran dari UKM dalam memperluas pasar domestik dan internasional. Selain hal itu pemerintah memberikan program-program edukasi baik dalam saran dan prasarana yang memudahkan UKM untuk lebih meningkatkan pengetahuan, skill, dan modernisasi kegiatan usaha.

\section{METODE}

\subsection{Tempat dan Waktu Penelitian}

\subsubsection{Tempat Penelitian}

Penulis dalam kesempatan ini mengambil tempat penelitian di MINU ICP Bojonegoro dan MIM 10 Bojonegoro, dengan alasan:

1. MINU ICP Bojonegoro dan MIM 10 Bojonegoro merupakan lembaga pendidikan masing-masing di bawah naungan organisasi kemasyarakatan terbesar di Indonesia

\footnotetext{
31 Ibid,

${ }^{32} \mathrm{https} / / /$ dosenekonomi.com/ilmu-ekonomi/sdm/pengertian-masyarakat-ekonomi-asean, Diakses pada tanggal 27 Juli 2018

${ }^{33}$ http://blogpengertian.com/mea-adalah-masyarakat-ekonomi-asean/. Diakses pada tanggal 28 Juli 2018
} 
yaitu NU dan Muhammadiyah, lembaga tersebut merupakan wadah salah satu program kerja dalam mensejahterakan dan mencerdaskan kehidupan berbangsa dan bernegara.

2. Belum ada penelitian tentang pengembangan SDM lembaga pendidikan Islam dalam menghadapi era MEA.

3. Lokasi penelitian ini merupakan lembaga pendidikan yang bertujuan mencetak generasi yang unggul sejak dini supaya siap menghadapi perkembangan jaman modern.

Penulis mengambil lokasi penelitian di kedua sekolah tersebut bukan berarti dua sekolah itu sebagai sampel dari beberapa sekolah NU dan Muhammadiyah yang ada di Bojonegoro, akan tetapi sebagai tempat penelitian dikarenakan penelitian ini adalah penelitian kualitatif bukan penelitian kuantitatif yang biasanya menggunakan sampling dan populasi

\subsubsection{Waktu Penelitian}

Waktu penelitian penulis lakukan selama 7 bulan, yaitu dari bulan Juni 2018 sampai dengan Januari 2019.

\subsection{Subyek Penelitian}

Sumber data dari penelitian ini adalah literatur yang membahas tentang pengembangan SDM dan Manajemen Pendidikan Islam serta situasi dan data di lapangan yang dianggap representative dalam memberikan gambaran tentang manajemen lembaga pendidikan Islam.

Pengumpulan data dapat dilakukan melalui sumber data, sumber data dapat menggunakan sumber primer dan sumber sekunder. ${ }^{34}$ Sumber primer merupakan sumber data yang langsung memberikan data kepada pengumpul data, misalnya wawancara langsung dengan Kepala Sekolah MINU ICP Bojonegoro dan Kepala Sekolah MIM 10 Bojonegoro dan staf-stafnya yang menjalankan dalam pengembangan SDM pendidik, dengan tujuan untuk menggali lebih dalam dan mendapatkan informasi yang dibutuhkan secara detail dan menyeluruh. Sedangkan sumber sekunder merupakan sumber data yang tidak langsung memberikan data kepada pengumpul data, misalnya lewat dokumen, foto dan lain-lain yang berkaitan dengan data yang dibutuhkan peneliti di MINU ICP Bojonegoro dan MIM 10 Bojonegoro.

\subsection{Teknik Pengumpulan Data}

Data yang digunakan dalam penelitian ini diperoleh dari hasil:

\section{Pengamatan Langsung (Observasi),}

Observasi yang digunakan dalam penelitian ini adalah observasi peran serta sebagai pengamat. ${ }^{35}$ Jenis observasi ini digunakan dalam rangka memperoleh data yang lebih lengkap dan rinci melalui pengamatan secara seksama dengan jalan terlibat langsung sebagai peranan pengamatan. Dalam hal ini peneliti mengamati langsung terhadap kegiatan di MINU ICP Bojonegoro dan MIM 10 Bojonegoro dalam kaitan komparasi antara dua lembaga tersebut.

\section{Wawancara (Interview)}

Yang digunakan dalam penelitian ini adalah jenis wawancara terstruktur dan wawancara tidak terstruktur, menggunakan wawancara terstrukturdikarenkan peneliti mempersiapkan pertanyaan-pertanyaan akan diajukan kepada responden, tekhnik ini

\footnotetext{
${ }^{34}$ Sugiyono, Metode Penelitian Pendidikan pendekatan Kuantitatif, Kualitatif, dan R\&D (Bandung: Al Fabeta 2015) Cet. 22, h. 308. Sumber primer adalah sumber data yang langsung memberikan data kepada pengumpul data seperti wawancara, pengamatan dan angket. Sedangkan sumber sekunder adalah sumber data yang tidak langsung memberikan data kepada pengumpul data, misalnya mendapatkan data dari orang lain atau lewat dokumentasi.

${ }^{35}$ Lexy J. Moleong, Metodologi Penelitian Kualitatif, (Bandung:PT Remaja Rosdakarya,2016), cet.35, h.127.
} 
dengan tujuan untuk mencari jawaban terhadap hipotesis kerja. Tekhnik ini dilakukan karena akan dilakukan pertanyaan yang sama pada obyek penelitian. Sejumlah pertanyaannya akan disusun sebelumnya dan didasarkan atas masalah dalam rancangan penelitian. sedangkan wawancara tidak terstruktur di mana pertanyaan tidak disusun terlebih dahulu, malah disesuaikan dengan keadaan dan spontanitas dari responden. Pelaksanaan wawancara mengalir seperti dalam percakapan sehari-hari. ${ }^{36}$

Agar lebih bersifat alami sehingga diperoleh data-data yang akurat dan valid, peneliti sengaja melakukan wawancara yang bersifat informal, lebih bersifat semacam obrolan. Bahkan untuk masalah penelitian tertentu, informan tidak mengetahui jika dirinya dijadikan sumber data atau dalam istilah Moleong disebut Wawancara Tertutup. ${ }^{37}$

\section{Dokumentasi}

Dalam menggali data dari dokumentasi, peneliti berusaha mencari, mengumpulkan dan meneliti arsip-arsip yang dimiliki MINU ICP Bojonegoro dan MIM 10 Bojonegoro khususnya yang berkaitan dengan komparasi antara dua lembaga tersebut.

Dengan demikian dokumen yang dipakai dalam penelitian ini meliputi dokumen internal, berupa kegiatan dalam peningkatan SDM di MINU ICP Bojonegoro dan MIM 10 Bojonegoro, Kegiatan prestasi di MINU ICP Bojonegoro dan MIM 10 Bojonegoro, Buletin, buku-buku, dan literatur lainnya.

\subsection{Teknik Pengolahan dan Analisis Data}

Analisis data dalam penelitian ini dilakukan secara fleksibel artinya tidak kaku oleh batasan kronologis selama berlangsungnya atau pasca pengumpulan data. Analisis data dalam penelitian ini mengacu pada metode perbandingan tetap (constant comparative method) seperti yang dikemukakan oleh Glaser dan Strauss dalam kutipan Lexy J. Moleong, buku Metodologi Penelitian Kualitatif. ${ }^{38}$ dinamakan metode perbandingan tetap atau constant comparative method karena dalam analisis data, secara tetap membandingkan satu datum dengan datum yang lain, dan kemudian secara tetap membandingkan katagori dengan katagori lainnya. ${ }^{39}$

Setelah data selesai dikumpulkan dengan lengkap, tahap berikutnya yang harus ditempuh adalah tahap analisa. Ini adalah tahap yang penting dan menentukan. Pada tahap ini data dikerjakan dan dimanfaatkan sedemikian rupa sampai berhasil menyimpulkan kebenaran-kebenaran yang dapat dipakai untuk menjawab persoalanpersoalan yang diajukan dalam penelitian. Teknik analisis data yang penulis gunakan dalam penelitian ini adalah analisis data kualitatif, mengikuti konsep yang diberikan Miles dan Huberman. Miles dan Huberman, sebagaimana dikutip oleh Sugiono mengemukakan bahwa aktivitas dalam analisis data kualitatif dilakukan secara interaktif dan berlangsung secara terus menerus pada setiap tahapan penelitian sehingga sampai tuntas, dan datanya sampai jenuh. Aktifitas dalam analisis data, yaitu : data reduction, data display, dan conclusion drawing/verification. ${ }^{40}$

1. Data reduction (reduksi data)

\footnotetext{
${ }^{36}$ Lexy J. Moleong, Metodologi Penelitian Kualitatif, h. 190

${ }^{37}$ Lexy J. Moleong, Metodologi Penelitian Kualitatif, h. 137

${ }^{38}$ Lexy J. Moleong, Metodologi Penelitian Kualitatif, hlm. 287

${ }^{39}$ Lexy J. Moleong, Metodologi Penelitian Kualitatif, hlm 288

${ }^{40}$ Sugiyono, Metode Penelitian Pendidikan, (Bandung: Alfabeta .2016), h.378
} 
Data yang diperoleh di lapangan cukup banyak, untuk itu maka perlu dicatat secara teliti dan rinci. Mereduksi data berarti merangkum, memilih halhal pokok, menfokuskan pada hal-hal yang penting, dan dicari tema dan polanya. Dengan demikian data yang telah direduksi akan memberikan gambaran yang lebih jelas, dan mempermudah peneliti untuk melakukan pengumpulan data selanjutnya.

Adapun tahapan-tahapan dalam reduksi data meliputi: membuat ringkasan, mengkode, menelusur tema dan menyusun laporan secara lengkap dan terinci.

Tahapan reduksi dilakukan untuk menelaah secara keseluruhan data yang dihimpun dari lapangan, yaitu Implementasi Pengembangan Manajemen SDM lembaga Pendidikan Islam dalam menghadapi tantangan MEA, sehingga dapat ditemukan hal-hal dari obyek yang diteliti tersebut. Kegiatan yang dapat dilakukan dalam reduksi data ini antara lain: 1) mengumpulkan data dan informasi dari catatan hasil wawancara dan hasil observasi; 2) serta mencari halhal yang dianggap penting dari setiap aspek temuan penelitian.

2. Data display (penyajian data)

Setelah data direduksi, maka langkah selanjutnya adalah mendisplaykan data, karena penelitian ini adalah penelitian kualitatif deskriptif maka data dalam penelitian ini akan disajikan dalam bentuk kata-kata atau uraian. Dengan mendisplaykan data, maka akan memudahkan untuk memahami apa yang terjadi dan merencanakan kerja selanjutnya berdasarkan apa yang telah dipahami tersebut. $^{41}$

Penyajian data dalam hal ini adalah penyampaian informasi berdasarkan data yang diperoleh dari MI ICP Nurul Ulum dan MIM 10 Klepek sesuai dengan fokus penelitian untuk disusun secara baik, runtut sehingga mudah dilihat, dibaca dan dipahami tentang suatu kejadian dan tindakan atau peristiwa yang terkait dengan Pengembangan Manajemen SDM lembaga Pendidikan Islam dalam menghadapi tantangan MEA dalam bentuk teks naratif.

Pada tahap ini dilakukan perangkuman terhadap penelitian dalam susunan yang sistematis untuk mengetahui Pengembangan Manajemen SDM lembaga Pendidikan Islam dalam menghadapi tantangan MEA di MI ICP Nurul Ulum dan MIM 10 Klepek. Kegiatan pada tahapan ini antara lain: 1) membuat rangkuman secara deskriptif dan sistematis, sehingga tema sentral dapat diketahui dengan mudah; 2) memberi makna setiap rangkuman tersebut dengan memperhatikan kesesuaian dengan fokus penelitian. Jika dianggap belum memadai maka dilakukan penelitian kembali ke lapangan untuk mendapatkan data-data yang dibutuhkan dan sesuai dengan alur penelitian.

\section{Conclution drawing/verification}

Setelah data direduksi dan disajikan langkah selanjutnya adalah penarikan kesimpulan dan verifikasi. Dalam penelitian, penarikan kesimpulan juga sekaligus menjawab rumusan masalah yang telah dirumuskan sebelumnya.

Pada tahap ini dilakukan pengkajian tentang kesimpulan yang telah diambil dengan data pembanding teori tertentu; melakukan proses member check atau melakukan proses pengecekan ulang, mulai dari pelaksanaan pra survey (orientasi), wawancara, observasi dan dokumentasi, dan membuat kesimpulan umum untuk dilaporkan sebagai hasil dari penelitian yang telah dilakukan.

\footnotetext{
${ }^{41}$ Sugiyono, Metode Penelitian Pendidikan, h. 341
} 
Kesimpulan yang ditarik perlu melihat dan meninjau kembali pada catatan-catatan lapangan di MI ICP Nurul Ulum dan MIM 10 Klepek untuk memperoleh pemahaman yang lebih tepat.

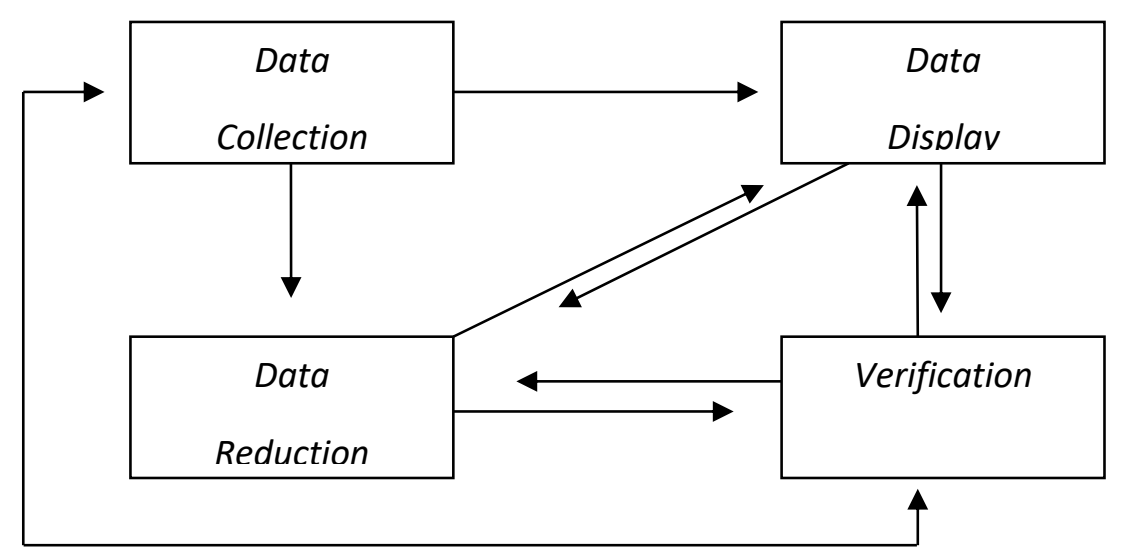

\section{Gambar 11. Siklus Proses Analisis Data (Model Miles dan Huberman)}

\subsection{Teknik Pemeriksaan dan Keabsahan Data}

Untuk menetapkan keabsahan (trustworthiness) data diperlukan teknik pemeriksaan. Teknik yang digunakan dalam pemeriksaan keabsahan data pada penelitian ini melalui Triangulasi dan Pengecekan sejawat. Triangulasi adalah teknik pemeriksaan keabsahan data yang memanfaatkan sesuatu yang lain di luar data itu untuk keperluan pengecekan atau sebagai pembanding terhadap data itu. Teknik triangulasi yang paling banyak digunakan ialah pemeriksaan melalui sumber lainnya. ${ }^{42}$ Tentang Pengecekan sejawat, teknik ini dilakukan dengan cara mengekpos hasil sementara atau hasil akhir yang diperoleh dalam bentuk diskusi dengan rekan-rekan sejawat. ${ }^{43}$

Untuk menguji keabsahan data yang didapat sehingga benar-benar sesuai dengan tujuan dan maksud penelitian, maka peneliti menggunakan teknik triangulasi. Triangulasi adalah teknik pemeriksaan keabsahan data yang memanfaatkan sesuatu yang lain di luar data itu untuk keperluan pengecekan atau sebagai pembanding terhadap data itu ${ }^{44}$

Moleong dalam bukunya menyebutkan bahwaa menurut Dezin bahwa triangulasi dibedakan menjadi empat macam triangulasi yaitu triangulasi sebagai teknik pemeriksaan yang memanfaatkan penggunaan sumber, metode, penyidik, dan teori. ${ }^{45}$ Adapun triangulasi yang digunakan dalam penelitian ini adalah triangulasi dengan sumber dan metode, yang berarti membandingkan dan mengecek derajat balik kepercayaan suatu informasi yang diperoleh melalui waktu dan alat yang berbeda dalam metode kualitatif.

\section{HASIL PEMBAHASAN}

4.1 Implementasi Pengembangan Manajemen Sumber Daya Manusia di MINU ICP Bojonegero 4.1.1 Temuan Hasil Penelitian

Manajemen pengembangan sumber daya manusia merupakan suatu kegiatan dalam upaya penyiapan tenaga pendidik yang prfesional, mulai dari perencanaan, rekrutmen,

\footnotetext{
${ }^{42}$ Lexy J. Moleong, Metodologi Penelitian Kualitatif, h. 330

${ }^{43}$ Lexy J. Moleong, Metodologi Penelitian Kualitatif, h 332

${ }^{44}$ Lexy J. Moleong, Metodologi Penelitian Kualitatif, h. 330.

${ }^{45}$ Lexy J. Moleong, Metodologi Penelitian Kualitatif, h. 330
} 
pembinaan dan pemberian kompensasi. Hal ini terangkum dalam wawancara dengan pimpinan MINU ICP Bojonegoro.

"manajemen pengembangan tenaga pendidik di madrasah adalah rangkaian kegiatan berupa perencanaan pengadaan tenaga pendidik yang disesuaikan dengan kebutuhan madrasah, proses rekrutmennya melalui seleksi, pembinaan dan pemberian kompensasi. Hal ini dilakukan agar dapat mendukung terwujudnya Visi dan Misi madrasah" 46

Kemudian dalam melakukan pengembangan sumber daya guru madrasah dengan upaya untuk melakukan perencanaan sejumlah tenaga pendidik, proses rekrutmen atau pembinaan, penilaian serta kompensasi yang dilakukan oleh pihak madrasah disesuaikan dengan kebutuhan dan kemampuan yang dimiliki lembaga sebagai berikut:

1) Kebijakan SDM tenaga pendidik

Pada kebijakan sumber daya manusia, MINU ICP Bojonegoro memliki perencanaan. Namun perencanaan ini menjadi dua macam yaitu perencanaan pengadaan sumber daya pendidik baru dan perencanaan yang bersifat pembinaan tenaga pendidik yang lama. Untuk perencanaan tenaga pendidik baru dilakukan sesuai dengan kebutuhan. Apabila ada tenaga pendidik yang mengundurkan diri dengan berbagai alasan dan berdampak kepda kekosongan tenaga pendidik maka madrasah melakukan rekrutmen tenaga pendidik yang baru dengan beberapa pertimbangan yang menjadi syarat diterimanya sesorang menjadi tenaga pendidik. Akan tetapi kepala madrasah sebelum melakukan pertimbangan terlebih dahulu calon tenaga pendidik menajalani kontrak kerja selama tiga atau enam bulan. Hal ini untuk mengetahui kinerja dan motivasi kerja tenaga pendidik di madrasah. Adapun dari sisi pembinaan guru dengan melakukan program pembinaan, pengarahan kepada tenaga pendidik dalam setiap mingguan dan bulanan.

2) Rekrutmen tenaga pendidik

Dalam rekrutmen calon tenaga pendidik, kepala sekolah berkoordinasi dengan guru ketika ada kekosongan atau lowongan tenaga guru dengan memberitahukan kepada teman atau tetangga dekat untuk bisa mengisi kekosongan tersebut. Kemudian pihak sekolah melakukan pemberitaan melalui media sosial dan radio jika tidak ada referensi dari guru-guru yang mengajar di MINU ICP Bojonegoro. Hal ini terangkum dalam wawancara dengan kepala sekolah MINU ICP Bojonegoro Bapak M. Wachid Iswahyudi.

"untuk rekrutmen kita memasukan info di media sosial bahkan di radio. Hal ini sesuai dengan kebutuhan guru pagi dan guru sore kita sampaikan apakah masih membutuhkan guru apa tidak. Dan jika masih membutuhkan maka diperioritaskan kita info guru-guru disini untuk disampaikan ke koleganya."47

Metode yang digunakan dalam rekrutmen calon pendidik di MINU ICP Bojonegoro selama ini melalui seleksi keselarasan prinsip dan tujuan sekolah dengan mengetahui dan mengkokohkan niat untuk berjuang dalam mengabdi mencerdaskan anak bangsa. Hal ini kepala sekolah memberikan kesempatan untuk magang selama enam bulan untuk mengetahui keikhlasan dan kesamaan prinsip dari sekolah. Kebijakan ini untuk mempermudah sekolah dalam menjalankan visi dan misi serta tujuan sekolah. Jika selama enam bulan calon tenaga pendidik mengalami kesulitan dan keberatan menjalankan prinsip sekolah, maka kepala sekolah tidak menerima keinginan untuk mengajar di MINU ICP Bojonegoro.

"ketika kita ada guru yang masuk kita interview dan memberikan pengarahan dan pengertian sesuai prinsip sekolah kami kemudian kita berikan waktu 6 bulan untuk masa uji coba mengajar di sekolah. Jika terdapat guru tidak sesuai dengan tujuan dan karakter sekolah ini, maka kami beri peringatan dan kami beri masukan selama enam bulan. Sampai enam

\footnotetext{
${ }^{46}$ Ibu Nurul Kusna, Pimpinan MI ICP Nurul Ulum Bojonegoro, Wawancara Pribadi, tanggal 16 Oktober 2018

${ }^{47}$ M. Wachid Iswahyudi, Kepala MINU ICP Bojonegoro, Wawancara Pribadi, tanggal 16 Oktober 2018
} 
bulan dia memenuhi kriteria kami, maka secara otomatis kami angkat jadi guru di sekolah ini. Dan jika tidak sanggup menjalankan kriteria syarat di sekolah ini yang kami lakukan penilaian berkala, maka kami tidak menerima keinginan dia untuk mengajar disini." 48

Selama ini rekrutmen calon tenaga pendidik tidak mengukur dari linier gelar sarjana atau kejeniusan dalam materi dan teori, akan tetapi yang di terima adalah calon tenaga pendidik yang mempunyai prinsip dan tujuan sama dengan prinsip sekolah sekaligus mau berusaha dan bekerja mendidik siswa dengan optimal.

"ada calon guru yang secara nilai coumlude akan tetapi tidak sesuai dengan prinsip kerja di sekolah ini maka kami tidak terima. Kami tidak mengukur lulus sarjana atau tidak akan tetapi mau berusaha dan berkerja dilapangan."49

3) Pembinaan Tenaga Pendidik

Pembinaan tenaga pendidik dapat diartikan sebagai upaya yang ditempuh lembaga dalam bentuk pengembangan (development) tenaga pendidik untuk memikul tanggung jawab yang tinggi dalam tugas dan jabatan yang diembannya.

MINU ICP Bojonegoro merupakan lembaga pendidikan yang memiliki visi misi yang cukup berat. Menyadari salah satu faktor penunjang keberhasilan pendidikan adalah didukung dengan kebradaan SDM tenaga pendidik yang berkualitas.

Dalam pembinaan tenaga pendidik, di MINU ICP Bojonegoro mempunyai rencana pembinaan SDM guru dalam bentuk pembinaan mingguan dan bulanan yang diberikan oleh pihak sekolah, kepala sekolah dan kurukulum. Ada tiga perencanaan yang dilakukan oleh pihak sekolah. Pertama pembinaan rutin yang dilakukan setiap hari selasa di tiap minggunya. Kedua pembinaan berupa peningkatan profesionalitas guru dengan adanya diklat yang bekerja sama dengan intansi lain. Ketiga pembinaan yang bersifat insidentil berupa penugasan kepada guru untuk mengikuti workshop peningkatan mutu pendidikan. Hal ini sesuai dengan apa yang dinyatakan oleh Ibu Ike Dewi Setiany, guru kelas 3 dalam wawancara berkut;

"Disini ada program pembinaan guru berlapis, yang dilakukan setiap seminggu sekali dan ada juga ketika permasalahan muncul itu langsung kita pembinaan. Ada yang rutinan tiap bulan sekali yang berkerja sama dengan instansi lain yaitu Rajekwesi dalam bidang psikologi, hal ini untuk mempelajari psikologi anak lebih dalam. Dalam pembinaan lain juga ada workshop dan diklat lainnya. Ada binaan dari pihak kurikulum untuk menyeragamkan pembelajaran disekolah. Dan ada juga untuk karakternya langsung dibina oleh teacher Nurul, Tidak boleh kita ngobrol sesama guru"50

Disamping kegiatan itu setiap bulan ada kegiatan kumpulan tenaga pendidik untuk diberi pembinaan, pembekalan ilmu keagamaan dan pendidikan karakter. Kegiatan in bertujuan agar guru memiliki pemahaman, kemampuan dalam bidang keagamaan dan memberi motivasi dalam bekerja. Ini ditegaskan oleh pimpinan sekolah yaitu Ibu Nurul Kusna.

"Mencetak orang pinter itu mudah, tapi membangun orang yang mau berkerja itu agak sulit. Kita arahkan agar menguasai materi dan menamkan kesadaran diri pada guru. Didalam kegiatan kita adakan tiap bulan kajian kitab klasik (kitab ala pesantren NU) dan motivator keagamaan agar emosional releginya terbangun, seperti kesadaran berkerja, kesabaran dan keikhlasan."

\footnotetext{
${ }^{48}$ M. Wachid Iswahyudi, Kepala MINU ICP Bojonegoro, Wawancara Pribadi, tanggal 16 Oktober 2018

${ }^{49}$ M. Wachid Iswahyudi, Kepala MINU ICP Bojonegoro, Wawancara Pribadi, tanggal 16 Oktober 2018

${ }^{50}$ Ike Dewi Setiany, guru kelas 3 MI ICP Nurul Ulum Bojonegoro, Wawancara Pribadi, tanggal 8 Januari 2019

${ }^{51}$ Ibu Nurul Kusna, Pimpinan MI ICP Nurul Ulum Bojonegoro, Wawancara Pribadi, tanggal 16 Oktober 2018
} 
4) Kompensasi tenaga pendidik

MINU ICP Bojonegoro sebagai lembaga pendidikan juga memiliki kebijakan kompensasi kepada tenaga guru yang mengabdi dan mengajar di MINU ICP Bojonegoro. Kompensasi di dalam manajemen berkaitan erat dengan pengeluaran biaya bagi perusahaan. Dalam manajemen kompensasi yang diberikan oleh karyawan diharapkan akan memperoleh imabalan prestasi kerja dari karyawan dalam menghasilkan suatu produk untuk mencapai keuntungan yang besar dan kontinuitas perusahaan terjamin. Dalam sudut pandang di lembaga pendidikan islam meskipun juga kompensasi juga dipertimbangkan untuk memotifasi pengabdian pendidik dalam melaksanakan tugas mendidik siswa. Akan tetapi kompensasi juga diberikan kepada pendidik yang mengembang tugas dari sekolah sesuai dengan masa pengabdian dan profesionalitas pendidik. Hal ini terangkum dalam penjelasan dari wawancara Bapak Wachid selaku kepala sekolah MINU ICP Bojonegoro.

"MI ICP Nurul Ulum Bojonegoro sebagai lembaga pendidikan islam yang dibawah naungan LP Ma'arif terus berupaya meningkatkan mutu pendidiknya dengan berlandaskan visi dan misinya. Para guru atau tenaga pendidik disini di MI ICP Nurul Ulum Bojonegoro telah dibentuk dan dipersiapkan sebagai tenaga pendidik yang tidak selalu mengharapkan imbalan dari kelelahannya dan beratnya tugas. Segala sesuatunya dibangun atas dasar keikhlasan dalam memberikan ilmu agama untuk memperjuangkan kecerdasan anak muslim di Indonesia. Namun pihak sekolah tetap memiliki kebijakan berupa pertimbangan berupa memberi kompensas sesuai dengan kemampuan yang dimiliki sekolah MI ICP Nurul Ulum Bojonegoro, meskipun kompensasi tidak setara dengan UMK akan tetapi usaha kepala sekolah tahun depan akan disetarakan dengan UMK Kabupaten Bojonegoro. Hal ini untuk memberi motifasi para guru sebagai tenaga pendidik agar meninkatkan kinerja pengabdiannya." 52

Hal ini juga dikuatkan oleh pernyataan yang disampaikan seorang guru saat diwawancarai beliau menyatakan sebagai berikut;

Dalam pengabdian kami pimpinan memberikan pengertian untuk keikhlasan mengabdi untuk agama berupa beramal untuk mencerdaskan anak bangsa melalui mengajar di lembaga pendidikan islam. Makanya sejak awal masuk kami ditanya oleh kepala sekolah niat kamu apa mau bergabung disini ?, kalau hanya untuk mengejar gaji disini sebaiknya jangan disini, karena disini gajinya tidak banyak. Sedangkan Untuk kompensasi ada gaji pokok, ada tunjangan ketika ada kegiatan tambahan, lembur dll. Untuk kompensasi ada perbedaan di lihat tunjangan dan jabatan, semakin jobnya tinggi maka kompensasinya juga tinggi" 53

Hal ini sesuai dengan hadits Rasul terkait dengan niat sebagai langkah awal dalam melakukan aktifitas yang diriwayatkan oleh Abi Hafs sebagai berikut:

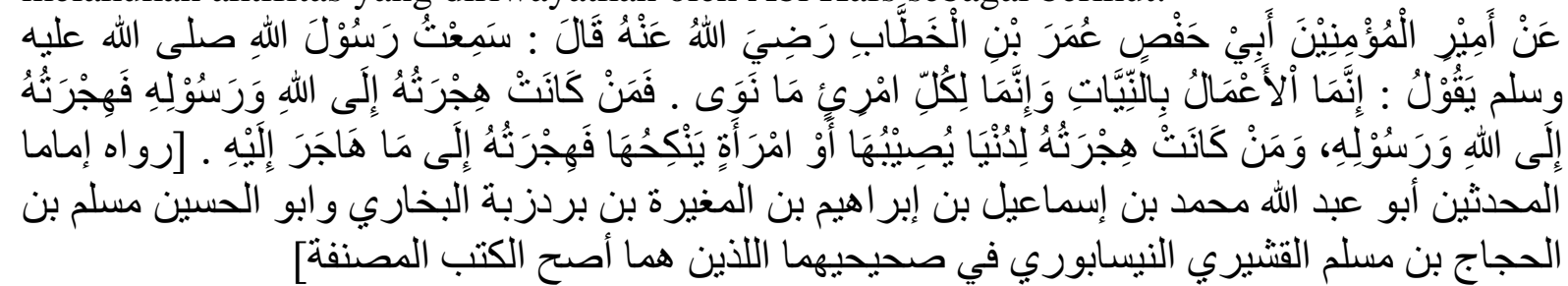

Artinya: "Dari Amirul Mu'minin, Abi Hafs Umar bin Al Khottob radiallahuanhu, dia berkata: Saya mendengar Rasulullah SAW bersabda: Sesungguhnya setiap perbuatan tergantung niatnya. Dan sesungguhnya setiap orang (akan dibalas) berdasarkan apa yang dia niatkan. Siapa yang hijrahnya karena (ingin mendapatkan keridhaan) Allah dan Rasul-

\footnotetext{
${ }^{52}$ M. Wachid Iswahyudi, Kepala MI ICP Nurul Ulum Bojonegoro, Wawancara Pribadi, tanggal 16 Oktober 2018

${ }^{53}$ Bapak Zamroni , Guru Bahasa Arab MI ICP Nurul Ulum Bojonegoro, Wawancara Pribadi, tanggal 25 Desember 2018
} 
Nya, maka hijrahnya kepada (keridhaan) Allah dan Rasul-Nya. Dan siapa yang hijrahnya karena dunia yang dikehendakinya atau karena wanita yang ingin dinikahinya maka hijrahnya (akan bernilai sebagaimana) yang dia niatkan. (Riwayat dua imam hadits, Abu Abdullah Muhammad bin Isma'il bin Ibrahim bin Al Mughirah bin Bardizbah Al Bukhori dan Abu Al Husain, Muslim bin Al Hajjaj bin Muslim Al Qusyairi An Naishaburi dan kedua kita Shahihnya yang merupakan kitab yang paling shahih yang pernah dikarang) ${ }^{54}$

\subsection{Implementasi Pengembangan Manajemen Sumber Daya Manusia di Madrasah Ibtidaiyah Muhammadiyah 10 Bojonegoro}

\subsubsection{Hasil Penelitian}

MIM 10 Bojonegoro memberikan proses manajemen pengembangan guru yang sesuai dengan strategi yang dialakukan oleh Madrasah Ibtidaiyah Muhammadiyah 10 Klepek Bojonegoro. Dengan adanya manajemen tersebut di sekolah ini diharapkan akan memperoleh guru yang berkualitas yang berdampak kepada berhasilnya tujuan pendidikan di sekolah ini.

Hal ini menjadi suatu upaya bahwa Madrasah Ibtidaiyah Muhammadiyah 10 Klepek Bojonegoro adalah sebagai lembaga pendidikan yang dibawah nauangan organisasi Muhammadiyah mau tidak mau harus berhadapan dengan perkembangan zaman saat ini terutama akan dihadapkan oleh pasar global, untuk itu Madrasah Ibtidaiyah Muhammadiyah 10 Klepek Bojonegoro terus meningkatkan kualitasnya diantaranya adalah dengan mental dan karakter siswa melalui manajemen pengembangan sumber daya manusianya. Sebagaimana kita ketahui bahwa keberhasilan suatu usaha manusia itu berkaitan erat dengan kualitas sumber daya manusia

Manajemen pengembangan sumber daya manusia merupakan suatu kegiatan dalam upaya penyiapan tenaga pendidik yang prfesional, mulai dari perencanaan, rekrutmen, pembinaan dan pemberian kompensasi. Hal ini terangkum dalam wawancara dengan kepala sekolah Madrasah Ibtidaiyah Muhammadiyah 10 Klepek Bojonegoro.

"dalam suatu lembaga pendidikan memang tidak terlepas dari manajemen. Dalam manajemen pengembangan sumber daya manusaianya, sekolah ini melakukan adanya perencanaan terlebih dahulu mengenai kualitas guru yang dibutuhkan, kemudian rekrutmen guru jika dibutuhkan untuk mengisi kekosongan terutama kita tawarkan ke guru-guru disekolah ini barang kali ada relasi orang untuk mengisi kekosongan guru. Kemudian setelah dapat guru kita ada pembinaan guru untuk menjadikan guru yang mampu mengampu anak didiknya. Jika kinerja dan loyalitas dalam mengabdi disekolah ini sepatutnya sekolah ada memebrikan kompensasi kepada guru, tetapi sesuai dengan kemampuan keuangan sekolah",55

1) Kebijakan SDM tenaga pendidik

Pada kebijakan sumber daya manusia, MI Muhammadiyah 10 Klepek Bojonegoro memiliki kebijakan untuk kualitas guru. Persaingan era global telah dipenuhi segala macam teknologi canggih. Hampir semua bidang memanfaatkan hal itu untuk mendapatkan hasil maksimal. Bidang pendidikan perlu memanfaatkan bidang teknologi secara maksimal. SDM yang cakap dan terampil akan mendukung tercapainya program ini. Program komputerisasi, media-media audiovisual dapat dimanfaatkan sebagai saran pembelajaran efektif untuk memacu kreativtas siswa. Saat ini guru-guru dilibatkan dalam pelatihan komputer untuk menggali potensi ICT dalam pendidikan.

Untuk perencanaan tenaga pendidik baru dilakukan sesuai dengan kebutuhan. Apabila ada tenaga pendidik yang mengundurkan diri dengan berbagai alasan dan berdampak kepada kekosongan tenaga pendidik maka madrasah melakukan rekrutmen tenaga pendidik yang

\footnotetext{
${ }^{54}$ Idrus Al Kaff, 40 Hadits Pilihan, teramahan Hadits Arba'in Annawawiah (Bandung: Husaini, 1992), h. 9

${ }^{55}$ Bapak Ilham, Kepala MI Muhammadiyah 10 Bojonegoro, Wawancara Pribadi, tanggal 16 Oktober 2018
} 
baru dengan beberapa pertimbangan yang menjadi syarat diterimanya sesorang menjadi tenaga pendidik. Akan tetapi kepala madrasah sebelum melakukan pertimbangan terlebih dahulu calon tenaga pendidik menajalani kontrak kerja selama tiga atau enam bulan. Hal ini untuk mengetahui kinerja dan motivasi kerja tenaga pendidik di madrasah. Adapun dari sisi pembinaan guru dengan melakukan program pembinaan, pengarahan kepada tenaga pendidik dalam setiap mingguan dan bulanan.

2) Rekrutmen tenaga pendidik

Dalam rekrutmen calon tenaga pendidik, kepala sekolah berkoordinasi dengan guru ketika ada kekosongan guru dengan memberitahukan kepada teman atau tetangga dekat untuk bisa mengisi kekosongan tersebut. Kemudian pihak sekolah melakukan pemberitaan melalui media sosial dan radio jika tidak ada referensi dari guru-guru yang mengajar di MI Muhammadiyah 10 Klepek Bojonegoro. Hal ini terangkum dalam wawancara dengan kepala sekolah MI Muhammadiyah 10 Klepek Bojonegoro Bapak Ilham.

"untuk rekrutmen kita informasikan ke guru-guru barang kali ada koleganya untuk bisa gabung di sekolahini. Untuk kriterianya tidak dibatasi baik itu anggota muhammadiyah maupun tidak.." 56

Sama dengan MI ICP Nurul Ulum, dalam metode yang digunakan dalam rekrutmen calon pendidik di MI Muhammadiyah 10 Klepek Bojonegoro selama ini melalui seleksi keselarasan prinsip dan tujuan sekolah dengan mengetahui dan mengkokohkan niat untuk berjuang dalam mengabdi mencerdaskan anak bangsa. Hal ini kepala sekolah memberikan kesempatan untuk magang selama tiga bulan untuk mengetahui keikhlasan dan kesamaan prinsip dari sekolah. Kebijakan ini untuk mempermudah sekolah dalam menjalankan visi dan misi serta tujuan sekolah

“jika ada guru baru yang masuk kita interview dan memberikan pengarahan dan pengertian sesuai prinsip sekolah kami kemudian kita berikan waktu 3 bulan untuk masa uji coba mengajar di sekolah. Jika terdapat guru tidak sesuai dengan tujuan dan karakter sekolah ini, maka kami beri pengarahan. Sampai 3 bulan dia betah dan nyaman dengan keadaan sekolah MI Muhammadiyah 10 Klepek Bojonegoro, maka secara otomatis kami angkat jadi guru di sekolah ini. Dan ada juga yang selama uji coba mereka tidak nyaman dalam kondisi dan kebiasaan kami secara tidak langsung mereka mengundurkan diri." ${ }^{57}$

Selama ini rekrutmen calon tenaga pendidik tidak mengukur dari linier gelar sarjana, akan tetapi MI Muhammadiyah 10 Klepek Bojonegoro fleksibel asal calon tenaga pendidik yang mempunyai prinsip dan tujuan sama dengan prinsip sekolah sekaligus mau berusaha dan bekerja mendidik siswa dengan optimal.

3) Pembinaan Tenaga Pendidik

Pembinaan tenaga pendidik dapat diartikan sebagai upaya yang ditempuh lembaga dalam bentuk pengembangan (development) tenaga pendidik untuk memikul tanggung jawab yang tinggi dalam tugas dan jabatan yang diembannya.

MI Muhammadiyah 10 Klepek Bojonegoro merupakan lembaga pendidikan yang memiliki visi misi yang cukup berat. Menyadari salah satu faktor penunjang keberhasilan pendidikan adalah didukung dengan kebradaan SDM tenaga pendidik yang berkualitas.

Peningkatan kualitas tenaga pendidik harus ditunjang dengan pembinaan SDM melalui arahan-arahan Kepala madrasah, pelatihan-pelatihan, workshop dan jenis peningkatan pendidikan lainnya. Dengan kegiatan tersebut akan menambah wawasan, pola berfikir, pengalaman dan pengetahuan guru terhadap tugas-tugas mulia yang diembannya

\footnotetext{
${ }^{56}$ Ilham , Kepala MI Muhammadiyah 10 Klepek Bojonegoro, Wawancara Pribadi, tanggal 25 Desember 2018

${ }^{57}$ Ilham , Kepala MI Muhammadiyah 10 Klepek Bojonegoro, Wawancara Pribadi, tanggal 25 Desember 2018
} 
mendidik para murid di madrasah agar menjadi manusia yang bermanfaat kepada agama dan bangsa.

Dalam pembinaan tenaga pendidik, di MI Muhammadiyah 10 Klepek Bojonegoro mempunyai rencana pembinaan SDM guru dalam bentuk pembinaan mingguan dan bulanan yang diberikan oleh pihak sekolah, kepala sekolah dan kurukulum. Ada tiga perencanaan yang dilakukan oleh pihak sekolah. Pertama pembinaan rutin yang dilakukan setiap hari selasa di tiap minggunya. Kedua pembinaan berupa peningkatan profesionalitas guru dengan adanya diklat yang bekerja sama dengan intansi lain. Ketiga pembinaan yang bersifat insidentil berupa penugasan kepada guru untuk mengikuti workshop peningkatan mutu pendidikan. Hal ini sesuai dengan apa yang dinyatakan oleh guru kelas 5 dalam wawancara berkut;

"Disini ada program pembinaan guru, yang dilakukan setiap satu bulan sekali dan ada juga ketika permasalahan muncul itu langsung kita pembinaan. Dalam pembinaan lain juga ada workshop dan diklat lainnya." 58

4) Kompensasi tenaga pendidik

MI Muhammadiyah 10 Klepek Bojonegoro sebagai lembaga pendidikan juga memiliki kebijakan kompensasi kepada tenaga guru yang mengabdi dan mengajar di MI Muhammadiyah 10 Klepek Bojonegoro. Kompensasi dalam teori manajemen berkaitan erat dengan pengeluaran biaya bagi perusahaan. Dala teori manajemen kompensasi yang diberikan oleh karyawan diharapkan akan memperoleh imabalan prestasi kerja dari karyawan dalam menghasilkan suatu produk untuk mencapai keuntungan yang besar dan kontinuitas perusahaan terjamin. Dalam sudut pandang di lembaga pendidikan islam meskipun juga kompensasi juga dipertimbangkan untuk memotifasi pengabdian pendidik dalam melaksanakan tugas mendidik siswa. Akan tetapi kompensasi juga diberikan kepada pendidik yang mengembang tugas dari sekolah sesuai dengan masa pengabdian dan profesionalitas pendidik. Hal ini terangkum dalam penjelasan dari wawancara Bapak Yani selaku kepala sekolah MI Muhammadiyah 10 Klepek Bojonegoro.

"MI Muhammadiyah 10 Klepek Bojonegoro sebagai lembaga pendidikan islam yang dibawah naungan Muhammadiyah terus berupaya meningkatkan mutu pendidiknya dengan berlandaskan visi dan misinya. Para guru atau tenaga pendidik disini di MI Muhammadiyah 10 Klepek Bojonegoro telah dibentuk dan dipersiapkan sebagai tenaga pendidik yang tidak selalu mengharapkan imbalan dari kelelahannya dan beratnya tugas. Segala sesuatunya dibangun atas dasar keikhlasan dalam memberikan ilmu agama untuk memperjuangkan kecerdasan anak muslim di Indonesia. Namun pihak sekolah tetap memiliki kebijakan berupa pertimbangan berupa memberi kompensasi sesuai dengan kemampuan yang dimiliki sekolah MI Muhammadiyah 10 Klepek Bojonegoro, meskipun kompensasi tidak begitu banyak akan tetapi kompensasi ini berupa gaji pokok, tunjangan, dan kesejahteraan keluarga. Hal ini untuk memberi motifasi para guru sebagai tenaga pendidik agar meninkatkan kinerja pengabdiannya." $" 59$

Hal ini juga dikuatkan oleh pernyataan yang disampaikan seorang guru saat diwawancarai beliau menyatakan sebagai berikut;

Dalam pengabdian kami pimpinan memberikan pengertian untuk keikhlasan mengabdi untuk agama berupa beramal untuk mencerdaskan anak bangsa melalui mengajar di lembaga pendidikan islam. Makanya sejak awal masuk kami ditanya oleh kepala sekolah niat kamu apa mau bergabung disini ?, kalau hanya untuk mengejar gaji disini sebaiknya jangan disini, karena disini gajinya tidak banyak. Sedangkan Untuk kompensasi ada gaji

\footnotetext{
${ }^{58}$ Alim, guru kelas MI Muhammadiyah 10 Klepek Bojonegoro, Wawancara Pribadi, tanggal 25 Desember 2018

${ }^{59}$ Ilham , kepala MI Muhammadiyah 10 Klepek Bojonegoro, Wawancara Pribadi, tanggal 25 Desember 2018
}

62 | Mumtäz Vol. 3 No. 1, Tahun 2019 
pokok, ada tunjangan ketika ada kegiatan tambahan, lembur dll. Untuk kompensasi ada perbedaan di lihat tunjangan dan jabatan, semakin jobnya tinggi maka kompensasinya juga tinggi" 60

\section{KESIMPULAN}

Adapun upaya-upaya pengembangan sumber daya manusia pendidikaan di MINU ICP Bojonegoro dan MIM 10 Bojonegoro dalam menghadapi era MEA, di antaranya:
a. Mengikuti perkembangan jaman
b. Giat dalam palatihan dan wordshop
c. Berkomitmen untuk mencerdaskan anak bangsa
d. Berfikir untuk maju di masa yang akan datang

\section{SARAN}

Dalam kegiatan perencanaan SDM cukup baik tapi hendaknya dipertahankan dan ditingkatkan kualitasnya dengan adanya kerjasama dengan lembaga profesional didunia pendidikan agar dapat mengambil perbandingan guna mempertahankan kualitas perencanaan SDM. Begitu juga rekrutmen yang seharusnya dilakukan secara terbuka dengan melalui tahapan-tahapan yang ideal. Hal ini dimaksud untuk mencari tenaga pendidik yang unggul.

Dengan meningkatkan kesejahteraan tenaga pendidik yang berikan sekolah diharapkan bisa memberikan motifasi untuk meningkatkan kinerjanya mendidik dan mengajar siswa di sekolah.

\section{DAFTAR PUSTAKA}

Al Kaff, Idrus. 40 Hadits Pilihan teramahan Hadits Arba'in Annawawiah, Bandung: Husaini, 1992.

Alkandhalawi, Maulana Muhammad Zakariya. Fadhail A'mal. Bandung:Pustaka Ramdhan, 2000,edisi Revisi Bahasa Indonesia.

Al-Qur'an Transliterasi dan Terjemahan. Bandung: Sinar Baru Algensindo, 2011.

Arifin, Zainal. Konsep dan Model Pengembangan Kurikulum, Bandung: PT. Remaja Rosdakarya; 2011, Cet. I.

Badriyah, Mila. Manajemen Sumber Daya Manusia. Bandung: Pustaka Setia, 2017.

Baharudin, Pengembangan Lembaga Pendidikan Islam, Menuju Pengelolaan Profesional dan Kompetitif, Malang: UIN-Maliki Press, 2012, cet.II.

Baharudin dan Moh. Makin, Manajemen Pendidikan Islam, Malang: UIN-Maliki Malang Press, 2016.

Baharuddin dan Moh. Makin, Manajemen Pendidikan Islam ; Transformasi Menuju Sekolah atau Madrasah Unggul, Malang: UIN Maliki Press, 2016.

BrainFit Indonesia, Perkembangan Kemampuan Kognitif. https://www.brainfit.co.id/kemampuan-kognitif/. diakses pada tanggal 11 September 2018 pukul 09:59 WIB

Depdiknas.. Panduan Umum Dewan Pendidikan dan Komite Sekolah. Jakarta : Ditjen Dikdasmen, 2002.

Departemen Pendidikan Dan Kebudayaan, Manajemen Sekolah, 1999.

Dosen ekonomi.com. Pengertian Masyarakat Ekonomi ASEAN dan Tujuannya https://dosenekonomi.com/ilmu-ekonomi/sdm/pengertian-masyarakat-ekonomiasean, Diakses pada tanggal 27 Juli 2018

${ }^{60}$ Alim , guru kelas MI Muhammadiyah 10 Klepek Bojonegoro, Wawancara Pribadi, tanggal 25 Desember 
Fadli, Yazid Manajemen Strategik LP Ma'arif NU Kabupaten Kudus Dalam Upaya Pengembangan SDM Pendidik Periode 2013-2018. Tesis. Program Pascasarjana, Prodi Manajemen Pendidikan Islam, STAIN Kudus. 2015.

Farkhan, Pengertian Masyarakat Ekonomi ASEAN : https://khanfarkhan.com/pengertiantujuan-dan-ciri-ciri-mea-masyarakat-ekonomi-asean/, diakases pada tanggal 21 Januari 2019.

Fatah, Nanang. Landasan Manajemen Pendidikan, Bandung: Remaja Rosdakarya, 2004.

Fitriyanto, Rahmad. Manajemen Personalia Di Sekolah , http://rahmadfitriyanto.blogspot.com/2016/08/manajemen-personalia-disekolah.html. diakses pada tanggal 16 November 2018 pukul 19:39 WIB.

Ginanjar, M. Hidayat. "Tantangan dan Peluang Lembaga Pendidikan Islam di Era Masyarakat Ekonomi Asean (MEA)”, Edukasi Islami Jurnal Pendidikan Islam, IV, Juli 2015.

Hakim, Rosniati. Tantangan Dan Peluang Sistem Pendidikan Islam Berbasis Peningkatan Mutu, diakses dari http://tarbiyahiainib.ac.id, pada tanggal 4 Mei 2018 pukul 19.45 WIB.

Hamalik, Oemar. Manajemen Pengembangan Kurikulum, Bandung: Remaja Rosdakarya, 2006.

Hasbullah, Otonomi Pendidikan, Jakarta: Rajawali Pers, 2010, cet. III.

Jalal, Fasli dan Dedi Supriyadi, (ed) Reformasi Pendidikan Nasional Dalam Konteks Otonomi Daerah, Yogyakarta: Adicita Karya Nusa, 2007.

Mahyudin, dan Anis Masykur, Pedoman Penulisan Karya Ilmiah STAI al-Hkmah Jakarta, Jakarta: Pustaka Hikmah, 2018.

Malisi, M. Ali Sibram. Tantangan dan Peluang Pendidikan Islam Di Era MEA, Jurnal Transformatif (Islamic Studies) Vol.1 nomer 1. Pasca Sarjana IAIN Palangkaraya, 2017.

Moleong, Lexy J. Metodologi Penelitian Kualitatif, Bandung:PT Remaja Rosdakarya,2016, cet. 35 .

Muhaimin, dkk. Manajemen Pendidikan, Aplikasinya dalam Penyusunan rencana Pengembangan Sekolah/Madrasah, Jakarta: Kencana, 2012.

Notoatmodjo, Soekidjo. Pengembangan Sumber Daya Manusia, Jakarta: PT. Rineka Cipta, 2015.

Pidarta, Made. Manajemen Pendidikan Indonesia, Jakarta:PT. Rineka Cipta, 2004, cet.II.

Priansa, Donni Juni dan Sonny Suntani Setiana, Manajemen dan Supervisi Pendidikan, Bandung: CV Pustaka Setia, 2018.

Priyatna, Muhamad. Manajemen Pengembangan SDM Pada Lembaga Pendidikan Islam, Jurnal, Edukasi Islami Jurnal Pendidikan Islam vol.05, Januari 2016.

Raharjo, Muhamad Mu'iz. Manajemen Sumber Daya Manusia yang unggul, cerdas dan Berkarakter Islmai.Yogyakarta: Gava Media, 2011.

Rahmah, Noer dan Zaenal Fanani, Pengantar Manajemen Pendidikan, Malang: Madani, 2017.

Ramadhan, Bagus. Tingkat Daya Saing Negara-Negara Dunia Tahun 2017-2018, Indonesia Naik Peringkat! https://www.goodnewsfromindonesia.id/2017/10/04/tingkat-dayasaing-negara-negara-dunia-tahun-2017-2018-indonesia-naik-peringkat. Diakses pada tanggal 4 Mei 2018.

Rosyada, Dede. Madrasah dan Profesionalisme Guru, Depok,Kencana: 2017.

Rusman, Manajemen Kurikulum, Jakarata: PT. Raja Grafindo Persada : 2009, Seri II.

Saefullah, KH.U. Manajemen Pendidikan Islam, Bandung: CV. Pustaka Setia, 2014. 
Sahroji, Ahmad. Daftar Negara ASEAN dengan Peringkat Pendidikan Tertinggi, https://news.okezone.com/read/2017/11/24/18/1820178/daftar-negara-asean-denganperingkat-pendidikan-tertinggi. diakses pada tanggal 4 Mei 2018 pukul 19.30 WIB.

Setiawan, Rendi. Sejarah Pendidikan Muhammadiyah, http://rendidikdasmen.blogspot.com/. Diakses pada tanggal 23-9-2018 pukul 08:31 WIB

Sejarah MI ICP Nurul Ulum, http://www.miicp-nurululum.sch.id/halaman/detail/sejarah, diakses pada tanggal 25 Desember 2018.

Shihab, M.Quraish. Tafsir al-Mishbah, Jakarta:Lentera Hati, 2002.

Siswanto, Partisipasi Masyarakat Dalam Pendidikan Islam, Jurnal INSANIA vol.8 tahun 2011.

Sugiyono. Metode Penelitian Pendidikan, Bandung: Alfabeta .2016.

Sukiswa, Iwa. Dasar-Dasar Umum Menejemen Pendidikan, Bandung: Tarsito, 1986, Cet. II.

Suroso, G.T. Masyarakat Ekonomi Asean (MEA) dan Perekonomian Indonesia http://www.bppk.kemenkeu.go.id/id/publikasi/artikel/150-artikel-keuanganumum/20545-masyarakat-ekonomi-asean-mea-dan-perekonomian-indonesia. diakses pada tanggal 8 November 2018 pukul 11;28 WIB.

Wahab, Abdul Azis. Anatomi Organisasi Dan Kepemimpinan Pendidikan; Telaah terhadap organisasi dan pengelolaan organisasi pendidikan . Bandung: Alfabeta, 2008.

Webside MI ICP Nurul Ulum, Profil MI ICP Nurul Ulum Bojonegoro. http://www.miicpnurululum.sch.id/. Diakses pada tanggal 5 Mei 2018.

Wikipintar.com, Masyarakat Ekonomi ASEAN. http://blogpengertian.com/mea-adalahmasyarakat-ekonomi-asean/. Diakses pada tanggal 28 Juli 2018

Wawancara :

Yani, Ahmad. Kepala MI Muhammadiyah 10 Bojonegoro, Wawancara Pribadi, tanggal 16 Oktober 2018

Zamroni. Guru Bahasa Arab MI ICP Nurul Ulum Bojonegoro, Wawancara Pribadi, tanggal 25 Desember 2018

Setiany, Ike Dewi. Guru kelas 3 MI ICP Nurul Ulum Bojonegoro, Wawancara Pribadi, tanggal 8 Januari 2019

Kusna, Nurul. Pimpinan MI ICP Nurul Ulum Bojonegoro, Wawancara Pribadi, tanggal 16 Oktober 2018

Iswahyudi , M. Wachid. Kepala MI ICP Nurul Ulum Bojonegoro, Wawancara Pribadi, tanggal 16 Oktober 2018

Ilham , Guru kelas MI Muhammadiyah 10 Klepek Bojonegoro, Wawancara Pribadi, tanggal 25 Desember 2018

Alim , Guru kelas MI Muhammadiyah 10 Klepek Bojonegoro, Wawancara Pribadi, tanggal 25 Desember 2018 